\title{
Does Peer Adoption Increase the Diffusion of Pollution Prevention Practices?
}

\author{
Xiang $\mathrm{Bi}^{\S, \dagger}$ \\ Conner Mullally \\ Shweta Gaonkar*
}

This version: January 5, 2020

\begin{abstract}
Voluntary adoption of pollution prevention (P2) practices has been used to reduce toxic emissions in the US. Spillovers among facilities owned by the same firm likely play an important role in the diffusion of $\mathrm{P} 2$ practices. This paper estimates the intrafirm spillover effects of P2 adoption. Using instrumental variables methods applied to facility panel data from the Toxics Release Inventory, we find that a facility's own adoption of P2 practices increases in response to greater P2 adoption by facilities from the same firm. Intrafirm spillovers are stronger among small firms and firms with higher degree of sibling homophily.
\end{abstract}

Key words: pollution prevention, Toxics Release Inventory (TRI), diffusion, spillovers, intrafirm spillovers

JEL Codes: Q55, Q58

$\S$ Corresponding author

$\dagger$ Assistant Professor of Food and Resource Economics, University of Florida, xiangbi@ufl.edu. PO Box 110240, Gainesville, FL 32611-0240, U.S.A.

* Assistant Professor of Food and Resource Economics, University of Florida, connerm@ufl.edu. PO Box 110240, Gainesville, FL 32611-0240, U.S.A.

*Assistant Professor of Carey Business School, Johns Hopkins University, gaonkar@jhu.edu, 100 International Drive, Baltimore, MD 21231, U.S.A. 


\section{1. Introduction}

2 Production-related toxic wastes in the United States declined from 37.16 to 30.57 billion

3 pounds from 1991 to 2017 (EPA, 2019), but reducing exposure to toxic wastes remains a

4 primary concern for the public (Hamilton, 1995; Konar and Cohen, 1997; Fung and

5 O'Rouke, 2000; Gruber, 2018). Significant reductions in toxic waste emissions can be

6 partly attributed to voluntary adoption of Pollution Prevention (P2) practices (Harrington

7 et al., 2014; Ranson et al., 2015; U.S. EPA, 2019). But observations from the Toxics

8 Release Inventory (TRI), a public information disclosure program on toxic emissions,

9 indicate that wide differences in the intensity of $\mathrm{P} 2$ adoption persist across firms as well as

10 within facilities owned by the same parent firm. Quantifying the factors driving such persist

11 heterogeneity will aid the policy push to reduce use of hazardous materials and greenhouse

12 gas emissions through P2 (Reibstein, 2009).

13 Use of $\mathrm{P} 2$ practices can be viewed through the lens of technology adoption and

14 diffusion. While a rich literature exists on the diffusion of technologies across firms, less

15 is known about intrafirm diffusion and characteristics of networks within firms that might

16 facilitate or hamper the spread of technology (Abrahamson and Rosenkopf, 1997; Guler et

17 al., 2002; Battisti and Stoneman, 2003; 2005; Hollenstein and Woerter, 2008). This gap in

18 the literature persists despite significant evidence for the important role played by

19 individual facilities and their managers in adopting new technologies and practices (Gupta

20 and Govindarajan, 2000; Van Everdingen and Wierenga, 2002; Battisti and Stoneman,

21 2003; Delmas and Toffel, 2004; 2008; Lenox and King, 2004; Doshi, Dowell, and Toffel,

22 2013). Improved understanding of intrafirm P2 adoption spillovers and the firm-level

23 characteristics that shape them could lead to better targeting of $\mathrm{P} 2$ promotion efforts. 
24 In this paper, we study intrafirm spillover effects in the context of P2 adoption.

25 More specifically, we estimate the extent to which an increase in P2 knowledge stock,

26 measured by the cumulative adoption of $\mathrm{P} 2$ practices among sibling facilities with the same

27 firm, increases own adoption of new P2 practices at the facility level. In addition, we

28 examine how the characteristics of the knowledge-sharing network linking facilities of the

29 same firm shapes the spillover effect of a change in knowledge stock. We use a panel

30 dataset consisting of 10,224 manufacturing facilities associated with all US firms that had

31 at least two TRI facilities at any point from 1991 through 2011. The length and

32 comprehensive nature of the TRI data allow us to examine two decades of P2 adoption by

33 public and private facilities that account for about $50 \%$ of U.S. manufacturing output

34 (Berchicci, 2013).

35 Time-varying unobserved firm-level shocks may affect the adoption of P2

36 practices, making sibling P2 stock endogenous in a regression model of own P2 adoption.

37 We address endogeneity by using twice-lagged state and federal inspections of sibling

38 facilities as instrumental variables. We control for each facility's own lagged P2 adoption,

39 facility size, own state and federal inspections, as well as fixed effects and time trends at

40 the firm level. Conditional on these factors, we expect that sibling inspections are only

41 correlated with facility's own P2 adoption through their correlation with lagged cumulative

42 adoption by siblings.

43 We find that a TRI facility will increase adoption of new P2 practices by $20-23 \%$

44 in response to a one standard deviation increase in the stock of P2 practices from siblings.

45 To explore how intrafirm network characteristics shape spillovers, we interact lagged

46 cumulative adoption by siblings with measures of each firm's geographic scope (number 
47 of states in which they operate), size (number of siblings), and similarity among siblings

48 (share of siblings belonging to the same industry). We find that larger firm size and

49 geographic scope impede the intrafirm diffusion of $\mathrm{P} 2$ practices, whereas a higher degree

50 of similarity among siblings enhances intrafirm diffusion. Our findings are robust to

51 alternative specifications where we change our set of covariates and instruments.

52 Most existing studies have focused on the effects of environmental inspection,

53 community pressure, state-level P2 policy, and implementation of environmental

54 management systems on P2 adoption by TRI facilities (Harrington, 2012, 2013; Khanna,

55 Deltas, and Harrington, 2009; Sam, 2010). Our work is most closely related to Harrington

56 (2012, 2013), who finds that a $10 \%$ increase in the average number of $\mathrm{P} 2$ practices adopted

57 by sibling facilities results in an increase in own facility-level P2 adoption of about 3\%.

$58 \quad$ We build on the work of Harrington $(2012,2013)$ and other previous studies in

59 several ways. First, the sample used in Harrington $(2012,2013)$ consists of firms listed in

60 the S\&P 500 from 1991 to 2001 . In contrast, we use a panel dataset of 10,224 facilities

61 from all firms with at least two TRI facilities observed from 1991 through 2011, potentially

62 giving our study strong external validity. Second, previous efforts to econometrically

63 identify the effect of sibling adoption of environmental practices on own adoption have

64 relied on Poisson fixed effects models without addressing endogeneity stemming from

65 time-varying unobservables (Harrington 2012, 2013). Our empirical strategy allows for

66 time-varying shocks that may be correlated with own adoption and knowledge stock from

67 the siblings but not with our instruments. 


\section{2. Background and related literature}

69 Disclosure of polluter P2 records through the highly-publicized TRI is one of the main

70 policy instruments used to encourage polluters to voluntarily reduce toxics, as some TRI

71 pollutants are not directly regulated (Khanna, 2001). The U.S. EPA established the TRI in

72 1987. All facilities above reporting thresholds ${ }^{i}$ in selected industries annually report

73 detailed information on their toxic emissions through direct releases and waste

74 management through treatment for each TRI-listed chemical. The TRI has experienced

75 several expansions since then, and the most significant extension was to include the

76 reporting of recycling and $\mathrm{P} 2$ practices in 1991.

77 The U.S. EPA maintains an information clearinghouse allowing firms to exchange

78 information on $\mathrm{P} 2$ while providing grants and technical assistance for P2 efforts (U.S. EPA,

79 2010). Around 36 U.S. states have their own P2 rules requiring additional reporting or

80 planning to encourage P2 adoption (O'Rouke and Lee, 2004; Harrington, 2013). The

81 disclosure rules associated with being listed in the TRI have motivated firms to voluntarily

82 adopt P2 practices, participate in voluntary environmental programs, and reduce toxic

83 emissions in response to pressure from the market, the public, and stakeholders (Hamilton,

84 1995; Khanna, 2001; King and Lenox, 2000; Maxwell and Decker, 2006; O'Rouke and

85 Lee, 2004; Bi and Khanna, 2012, 2017).

86 Adoption of $\mathrm{P} 2$ practices allows facilities to improve their environmental

87 performance in two ways. First, adopting P2 practices enables facilities to control costs

88 related to complying with environmental regulations (Christmann, 2000; Sam 2010;

89 Harrington, 2012, 2013), and may provide cost advantages over competitors (Christmann,

90 2000). Second, the pro-environmental signal sent by P2 adoption may reduce pressure on 
91 facilities from outside organizations like environmental interest groups and local

92 authorities (Konar and Cohen, 1997; Khanna, 2001; Khanna, Deltas, and Harrington, 2009;

93 Harrington, 2012 and 2013). As suggested by the literature on technology diffusion, the

94 total benefits of $\mathrm{P} 2$ adoption will depend on the intensity of adoption by subsidiaries within

95 firms as well as the number of firms adopting P2 practices (Battisti and Stoneman, 2003;

96 2005; Hollenstein and Woerter, 2008).

97 Although parent firms may make decisions regarding P2 adoption, enforcing 98 adoption by individual facilities may be challenging. Even if a parent firm pushes its

99 subsidiaries to uniformly adopt a given management practice, subsidiaries may vary in

100 their adoption intensity or not adopt at all because of heterogeneity in absorptive capacity

101 or responses to institutional pressure (Oliver, 1991; Rosenzweig and Singh, 1991; Tsai,

102 2001; Gupta and Govindarajan, 2000; Delmas and Toffel 2004; 2008; Escribana and Tribo,

103 2009; Doshi et al., 2013). In the case of environmental practices, case studies suggest that

104 subsidiary adoption is often much lower than expected by corporate management (Lenox,

105 King, and Ehrenfeld, 2000). Surveys of facility managers indicate that the decision to adopt

106 an environmental practice is often up to individual facility managers, and that managers

107 balance financial, environmental, community, and regulatory pressures from the parent

108 firm as well as external stakeholders while not considering impacts on other facilities

109 (Delmas and Toffel 2004; 2008).

110 Recognizing the limitation of the corporate top-down approach for promoting the

111 diffusion of P2, U.S. EPA published an organizational guide that encourages a systematic

112 bottom-up approach. This approach focuses on subsidiaries with parent firm endorsement

113 and dissemination (U.S. EPA, 2001) to initiate P2 innovations. Consistent with the 
114 approach taken by EPA, our conceptual and empirical framework consider facilities as the

115 decision makers regarding the adoption of $\mathrm{P} 2$ practices and examine how the practice of

$116 \mathrm{P} 2$ is adopted across facilities as a consequence of knowledge diffusion within a firm.

\section{3. Conceptual framework}

118 We assume that facilities update their expectations of the benefits of adopting a given P2

119 practice prior to making any new adoption decisions in the current period, and that the

120 updating process accounts for experience from own adoption and that of peers (Westphal,

121 Ranjay, and Shortell, 1997; Guler, Guillén, and Macpherson, 2002). P2 adoption is costly,

122 not only because a new $\mathrm{P} 2$ practice may require investment to adjust management practice,

123 production techniques, and equipment (Jaffe et al., 2003), but also because proper P2

124 implementation requires information and knowledge. A facility's own past P2 adoption

125 and the cumulative $\mathrm{P} 2$ adoptions by sibling facilities affects its present $\mathrm{P} 2$ adoption through

126 two channels: reducing costs (monetary and otherwise) of knowledge and information

127 acquisition and updating beliefs with respect to net benefits of $\mathrm{P} 2$ adoption. For example,

128 by observing the adoption practices of sibling facilities, facility managers can reduce the

129 cost of implementing new P2 practices by imitating the choices of successful siblings. By

130 learning from own past experience and from observing the experiences of sibling facilities,

131 facility managers can improve their ability to assimilate information on previously

132 unfamiliar P2 practices. Finally, own past experience with P2 adoption can have a

133 demonstration effect that makes it easier to leverage external support for additional P2

134 adoption. Each of these cost-reduction mechanisms is described in previous literature

135 (Lenox and King, 2004; Cohen and Levinthal, 1989). New knowledge and information 
136 acquired through own experience and that of sibling facilities is then used to update the

137 beliefs of facility managers prior to making additional P2 adoption decisions.

138 Descriptive evidence suggests that our assumptions are appropriate in the context

139 of P2. Harrington (2013) finds that a facility's P2 adoption in the current period is

140 correlated with its own lagged P2 adoption. In addition, the role of learning from peers is

141 supported by a large literature in technology adoption (e.g., Besley and Case, 1993; Doring

142 and Schnellenbach, 2006; Harrington, 2012; Brouhle, Graham, and Harrington, 2013). In

143 our study, the relevant set of peers consists of sibling facilities. The existing literature

144 suggest that facilities are more likely to trust and learn from their siblings than facilities of

145 other firms about new practices (Singh, 2005; Hollenstein and Woerter, 2008). But the ease

146 with which knowledge and information about P2 practices will diffuse among facilities of

147 a given parent company will depend on the intrafirm network linking sibling facilities. We

148 explore the issues above more formally in the next section.

150 Model of diffusion

151 To approximate the process of learning among sibling facilities and from own past

152 experience, we follow the theoretical framework outlined in Bass (1969) and applied by

153 Midgley, Morrison, and Roberts (1992) and Flight and Palmer (2013). ${ }^{\text {ii }}$ The original Bass

154 (1969) model was used to depict a S-shaped cumulative adoption curve of a product over

155 time and while assuming that the flow of information from earlier adopters moderated by

156 the existing number of adopters and total anticipated number of adopters over time (market 157 size) will shape the rate of adoption. 
As shown in equation (1), we adapt the Bass (1969) framework to the adoption of

159 P2 practices. In equation (1), P2 practices adopted in year $t$ by facility $i$ in a firm $j\left(T_{i j t}\right)$

160 are influenced by external communications from other facilities within a firm $\left(s_{(i) j t-1}\right)$.

161 The strength of the influence of other facilities is governed by a parameter $\left(P_{j t}\right)$ whose

162 value depends on the network linking facilities within the same firm. Other factors

163 affecting P2 adoption include the facility's ceiling on the total number of P2 practices that

164 can be adopted over the study period $\left(m_{i}\right)$, the facility's ability to internalize its previous

165 experience on adoption of $\mathrm{P} 2$ practices $\left(q_{i}\right)$, the facility's own cumulative adoption of $\mathrm{P} 2$

166 practices through the previous year $\left(\sum_{t=1}^{t-1} T_{i j t-1}\right)$, and other characteristics that might affect

167 diffusion $\left(X_{i j t}\right)$, such as technological changes affecting all facilities in the same industry,

168 shocks affecting all facilities in the same location, public and regulatory pressures to reduce

169 toxic emissions, and output demand shocks:

170

$$
T_{i j t}=\theta * P_{j t} * S_{(i) j t-1}+\beta * q_{i} * \frac{\sum_{t=1}^{t-1} T_{i j t-1}}{m_{i}} *\left(m_{i}-\sum_{t=1}^{t-1} T_{i j t-1}\right)+X_{i j t}{ }^{\prime} \gamma
$$

171 Note that $s_{(i) j t-1}=\sum_{k \neq i}^{J} \sum_{t=1}^{t-1} T_{k j t-1}$ (i.e. practices adopted by siblings through $t-1$

172 equals the sum of sibling adoption through $t-1$ ), and $J$ represents the total number of 173 facilities within firm $j$.

174 The functional form of equation (1) and the ceiling on P2 adoption given by $m_{i}$ 175 ensure that the relationship between time and total $\mathrm{P} 2$ practices adopted by facility $i$ can be

176 represented by an S-shaped curve, with total practices initially increasing at an increasing 177 rate, then increasing at a decreasing rate, and finally hitting an adoption ceiling. S-shaped 178 curves have been used to describe technology adoption since the classic work of Griliches 179 on hybrid corn (Griliches, 1957), on new product adoption (Bass,1969), and many other 
180 cases of diffusion (e.g., Mahaja et al., 1995; Bass, 2004). Other studies adopt the frame-

181 work of Bass to study intra-firm diffusion of organizational practices and innovations (e.g.,

182 Midgley et al., 1992; Flight and Palmer, 2013; Tsai, 2008; van Everdingen and Wierenga, 183 2002).

184 Equation (1) shows that as $P_{j t}$ increases, knowledge flow within the firm improves, 185 and the effect of cumulative sibling knowledge on the facility's decision to adopt P2 186 practices becomes stronger. Equation (1) also shows that cumulative sibling knowledge 187 indirectly affects facility $i$ 's adoption through own past adoption. As $s_{(i) j t-1}$ increases, $188 T_{i j t}$ and $\sum_{t=1}^{t-1} T_{i j t-1}$ will increase, and a higher value of $\sum_{t=1}^{t-1} T_{i j t-1}$ implies increased 189 adoption by facility $i$ in period $t+1\left(T_{i j t+1}\right)$. Furthermore, as the number of $\mathrm{P} 2$ practices 190 adopted by facility $i$ at time $t\left(\sum_{t=1}^{t-1} T_{i j t-1}\right)$ increases, the value of the spillover variable 191 affecting other facilities besides $i$ (e.g., $s_{(k) j t}$ for $k \neq i$ ) increases as well. The higher value 192 of the spillover variable faced by facilities other than $i$ at time $t$ will increase other facilities' 193 P2 adoption in period $t+1$. In other words, the effect of $s_{(i) j t-1}$ on $T_{i j t}$ is amplified over 194 time through multiple feedback channels.

195 Additionally, as facility $i$ 's own cumulative knowledge $\left(\sum_{t=1}^{t-1} T_{i j t-1}\right)$ increases, the 196 number of new practices adopted in the next period will increase but at a decreasing rate 197 as a result of the capacity limitation set by $m_{i}$ and the functional form of equation (1). As 198 the firm's ceiling of adoption $\left(m_{i}\right)$ increases, the adoption of new P2 practices increase 199 given that the partial derivative of $T_{i j t}$ with respect to $m_{i}$ is positive. As the facility's own 200 ability to internalize its past P2 knowledge $\left(q_{i}\right)$ increases, facility's new adoption of P2 201 practices will increase, because the marginal effect of $q_{i}$ is positive given $m_{i}$ is at least as 
202 large as $\sum_{t=1}^{t-1} T_{i j t-1}$. The marginal effect of cumulative adoption on current becomes zero

203 when $m_{i}=\sum_{t=1}^{t-1} T_{i j t-1}$ and the ceiling of the total number of $\mathrm{P} 2$ practices is reached.

204

\section{Factors affecting knowledge flow within a firm}

206 The existing literature shows a positive relationship between adoption of environmental 207 practices and the strength of connections among siblings (Ochsner and Chess, 1996; 208 Sharma and Vredenburg, 1998; Van Everdingen and Wierenga, 2002; Lenox and King, 209 2004; Bhupendra and Sangle, 2015). Features such as familiarity among members of a 210 network and homophily (i.e. similarity among members) can enhance knowledge 211 transmission within a network (Inkpen and Tsang, 2005; Kremer and Miguel, 2007; Oster 212 and Thornton, 2009; Szulanski, 1996).

213 We are interested in examining the impact of homophily on a facility's absorption

214 of previous knowledge generated by sibling P2 adoption. Therefore, we allow the impact 215 of lagged cumulative sibling P2 adoption to depend on the degree of similarity among 216 siblings. We approximate similarity by calculating the percentage of siblings that operate 217 in the same industry (where industry is classified by a facility's primary 2-digit SIC code).

218 We expect the strength of spillover effects to increase with the number of siblings operating 219 in the same industry.

220 We also test whether the intrafirm spillover effect is increasing or decreasing in 221 parent firm size. Information dissemination within a firm may depend on adjustment, 222 training employees, and intrafirm coordination (Jaffe, Newell and Stavins, 2003). Although 223 large firms may be better able to finance technology adoption than small firms (Karshenas 224 and Stoneman, 1993, 1995; Florida and Davison, 2001; Snyder, Miller, and Stavins, 2003), 225 small firms have been found to intensify their subsequent adoption faster than larger firms 
226 after the initial adoption of a new technology. Greater speed and intensity of adoption

227 among small firms may be a result of relatively low coordination and monitoring costs

228 (Fuentelsaz, Gomez, and Polo, 2003). At the same time, having a larger number of facilities

229 could translate into a greater quantity and diversity of knowledge and larger spillover

230 effects among siblings (Gupta and Govindarajan, 2000; Todo, Matous, and Inoue, 2016).

231 Additionally, the pattern of knowledge diffusion within a firm may be influenced

232 by the geographic dispersion of knowledge (Singh, 2005). To shed light on this possibility,

233 we explore the relationship between P2 diffusion and the geographic scope of operation.

234 Earnhart and Leonard $(2013,2016)$ find that facilities from firms that operate in multiple

235 states employ more environmental audits than other facilities. They suggest that firms

236 operating in multiple states are more visible to regulators and therefore more likely to

237 implement best practices in all subsidiaries to reduce potential regulatory conflicts. But

238 having operations across different states may increase the effort needed to disseminate

239 knowledge and reduce effective communication among subsidiaries. Previous studies show

240 that proximity between senders and recipients of information matters, as neighbors tend to

241 share informal social interactions, share more trust, use common resources, and face similar

242 pressures (Downing and White, 1986; Besley and Case, 1993; Jaffe, Trajtenberg, and

243 Henderson, 1993). Additionally, the effect of sibling's cumulative P2 adoption by an out-

244 of-state sibling facility may be small if facilities in different states face different

245 environmental issues or regulatory frameworks. Hence, we test whether the effect of P2

246 spillovers are positively or negatively correlated with the geographic scope of operation as

247 defined by the number of states in which a parent firm operates. 


\section{4. Empirical approach}

249 Given the above conceptual framework, we estimate the effects of own lagged P2 250 adoption ${ }^{\text {iii }}$ and cumulative P2 knowledge among sibling facilities on facility-level P2

251 adoption, while allowing the latter effect to vary with firm-level network characteristics.

252 We begin with the empirical specification shown in equation (2) below:

$$
T_{i j z d t}=\alpha_{i}+\delta_{j} t+\beta_{1} T_{i j z d t-1}+\beta_{2} S_{(i) j t-1}+X_{i j z d t-1}{ }^{\prime} \beta_{3}+P_{j t}{ }^{\prime} \beta_{4}+C_{z t}^{\prime} \beta_{5}+\rho_{d t}+\pi_{z t}+
$$

$254 s_{(i) j t-1} \times\left(P_{j t}-\overline{P_{j t}}\right)^{\prime} \theta+\lambda_{j t}+v_{i t}(2)$

In equation (2), the dependent variable $\left(T_{i j z d t}\right)$ represents the number of new P2

257 practices adopted by facility $i$ of firm $j$ in industry $d$ and state $z$ in year $t$, while $T_{i j z d t-1}$ is

258 its lag. Our main explanatory variable of interest, $s_{(i) j t-1}$, represents the cumulative 259 number of $\mathrm{P} 2$ practices adopted by sibling facilities of the same firm $j$ through year $t-1$.

260 Note that we use facilities that were siblings at time $t-1$ to calculate $s_{(i) j t-1}$, even if a

261 change in ownership occurred at time $t$. The vector $X_{i j t-1}$ contains facility characteristics

262 observed in year $t-1$, while $P_{j t}$ is a vector of firm $j$ 's network characteristics observed in 263 year $t$.

264 To absorb unobserved correlates of own P2 adoption that might also be correlated 265 with our main explanatory variables of interest, we include fixed effects for facility $i$, in266 dustry $d$ in year $t$, and state $z$ in year $t$. These fixed effects are given by $\alpha_{i}, \rho_{d t}$, and $\pi_{z t}$, 267 respectively. $\delta_{j} t$ is a firm-level linear time trend, $\lambda_{j t}$ is a time-varying shock that is shared 268 by all facilities in firm $j$, and $v_{i t}$ is a time-varying shock specific to facility $i$. Examples of 269 firm-specific or facility-specific shocks that would not be absorbed by industry-year or 
270 state-year fixed effects might include localized demand shocks, changes in ownership, or

271 unobserved changes in public pressure to adopt P2 practices directed at individual firms or

272 facilities. The latter two terms comprise the regression error. Note that we subtract sample

273 means from each network characteristics $P_{j t}$ prior to creating the interaction terms thereby

274 ensuring that $\beta_{2}$ in equation (2) is properly interpreted as the average marginal effect of

$275 S_{(i) j t-1}$ (Wooldridge, 2010).

276

\section{Variable construction}

278 The dependent variable in equation (2) is a non-negative integer, as only the adoption of 279 incremental (new) P2 practices are reported to TRI on an annual basis. ${ }^{\text {iv }}$ We use a log280 linear specification in estimation following Narayanan and Nair (2013). Specifically, we 281 applied the inverse hyperbolic sine transformation to convert the dependent variable into a 282 natural $\log$ value and to ensure positive conditional mean (Yen and Jones, 1997). ${ }^{\mathrm{v}}$ This log283 linear specification allows us to use instrumental variables to control for the endogeneity 284 of facility's own lagged adoption $\left(T_{i j z d t-1}\right)$ and cumulative number of practices adopted 285 by sibling facilities $\left(s_{(i) j t-1}\right)$, while controlling for large number of state, industry, and 286 year fixed effects. While an obvious alternative approach would be to use a Poisson model, 287 we are not aware of any Poisson estimators that are appropriate for high-dimensional fixed 288 effects, lagged dependent variables, and endogenous explanatory variables.

289 Our measure for $s_{(i) j t-1}$ is the total number of new P2 practices reported by sibling 290 facilities of the same parent firm, beginning in 1991 up to the preceding year. We refer to 291 this variable as Sibling P2 Stock hereafter. We use a cumulative measure because 292 knowledge is cumulative. Similar measures have been used in the literature to represent 
293 the "installed base" or the knowledge stock of earlier adoptions when examining the effect 294 of contagion in marketing (e.g., Narayanan and Nair, 2013). However, we check the 295 robustness of our results to allowing the effect of sibling knowledge to decay over time.

296 Our effect of interest is an example of what is known as an "endogenous effect" in 297 the networks literature, i.e. the response of individual behavior to group behavior. 298 According to Manski (1993), correlated effects (similar behavior among group members is 299 a result of shared characteristics or environments) and contextual effects (individual 300 behavior is a function of group characteristics) could give rise to spurious correlation 301 between adoption decisions at individual facilities and adoption decisions by siblings. To 302 minimize the risk of bias from contextual effects, we control for time-varying firm 303 characteristics $\left(P_{j t}\right)$ and firm-level time trends. The latter will control for firm-specific 304 unobserved determinants of P2 adoption that are changing systematically over time. Our 305 industry-year and state-year fixed effects will control for time-varying shocks common to 306 all facilities within an industry or state in a given year, purging our estimates of one 307 potential source of bias from correlated effects.

308 Facility-level covariates include the number of employees as in Lenox and King 309 (2004) and the amount of toxic releases reported by the facility in the previous period as in 310 Harrington $(2012,2013)$. Following previous studies, both variables are in natural log form

311 to reduce skewness and are lagged by one year. To control for the size of the firm relative

312 to other firms in the industry, we use Percentage of a Firm's Sales in an Industry (where 313 industry is defined by the 4-digit SIC code of the parent firm).

314 Finally, we control for the local industrial agglomeration effect using the number 315 of TRI facilities in a county. The clustering of toxic facilities can attract the attention of 
316 regulators (Gray and Shadbegian, 2007), which may lead facilities to adopt more P2 317 practices to abate pollution. Meanwhile, the number of toxic facilities could generate an 318 agglomeration effect that lowers the costs of adopting P2 practices. We include the 319 unemployment rate of the county in which the toxic facility is located to control for 320 community pressure on facilities to voluntarily adopt P2 practices and reduce reliance on

321 toxic materials (Earnhart, 2004). We would expect unemployment to be inversely related 322 with public pressure for reduced emissions.

323 To assess whether intrafirm spillover effects vary with network characteristics, we 324 allow the effect of $s_{(i) j t-1}$ to depend on network size, homophily, and geographic scope.

325 We create dummy variables based on the sample distribution of each network variables to 326 avoid imposing linearity of the impact of network variables on spillover effects. More 327 specifically, for each network characteristic we create two dummy variables: a dummy that 328 is equal to one for any facility with a value above the median for the network characteristics 329 in question and zero otherwise, and another dummy variable equal to one for facilities with 330 values above the $75^{\text {th }}$ percentile and zero otherwise. By interacting each of these dummy 331 variables with our measure of sibling knowledge, we can check whether the spillover effect 332 is a nonlinear function of firm size without imposing strong functional form assumptions.

333 We take the first difference of equation (2) prior to estimation, thereby eliminating 334 facility-level fixed effects as well as firm-level fixed effects for facilities that did not 335 change ownership over the observed time horizon.

336 After taking first differences, we have equation (3), in which $\delta_{j}$ represents the first337 differenced firm-specific linear time trend and $\Delta \lambda_{t}$ is the first-differenced firm-level 338 shocks. 


$$
\begin{gathered}
\Delta T_{i j z d t}=\delta_{j}+\Delta \mu_{t}+\beta_{1} \Delta T_{i j z d t-1}+\beta_{2} \Delta s_{(i) j t-1}+\Delta X_{i j z d t-1}^{\prime} \beta_{3}+ \\
\Delta\left[S_{(i) j t-1} \times\left(P_{j t}-\overline{P_{j t}}\right)\right]^{\prime} \theta+\Delta P_{j t}^{\prime} \beta_{4}+\Delta C_{t}^{\prime} \beta_{5}+\Delta \rho_{d t}+\Delta \pi_{z t}+\Delta \lambda_{j t}+\Delta v_{i t}
\end{gathered}
$$

342 Recall that $s_{(i) j t-1}$ is constructed by summing P2 adoption for sibling facilities through

343 year $t-1$, i.e. summing the dependent variable in equation (3) for all sibling facilities

344 through the previous year. Since $T_{i j z d t}$ is a function of $\lambda_{j t}$, and the latter is common to all

345 facilities of firm $j, s_{(i) j t-1}$ will be a function of the firm-specific shocks $\left\{\lambda_{j 1}, \ldots, \lambda_{j t-1}\right\}$.

346 After taking first differences, $\Delta T_{i j z d t}$ is a function of $\Delta \lambda_{j t}$ while $\Delta s_{(i) j t-1}$ is a function of

$347 \Delta \lambda_{j t-1}$. In other words, $\Delta s_{(i) j t-1}$ is endogenous in equation (3) even after taking first

348 differences. The sign of the bias will depend on the autocorrelation structure of $\Delta \lambda_{j t}$. If $\lambda_{j t}$

349 follows an AR(1) process or is not autocorrelated, estimates of the spillover effect that do 350 not address endogeneity will be downward biased. The sign of the bias is ambiguous under 351 more complex autocorrelation structures.

352 To deal with the endogeneity of $\Delta s_{(i) j t-1}$, we employ two instrumental variables:

353 the second lag of the average number of inspections of sibling facilities by the EPA, and 354 the second lag of the average number of inspections of sibling facilities by state agencies.

355 In other words, to calculate each instrument we add up the number of times sibling facilities

356 were inspected by the EPA or state agencies (as the case may be) and divide by the number 357 of siblings. For environmental inspections, we focus on inspections under the Clean Air

358 Act (CAA) because $78 \%$ of the toxic air releases reported in the TRI are emitted into the 359 air (EPA, 2019; Harrington, 2012, 2013).

360 For our instruments to be valid, they must have predictive power with respect to

361 lagged cumulative sibling P2 adoption and satisfy the exclusion restriction. We use the 
362 second lag of inspections to predict the first lag of cumulative sibling P2 adoptions because

363 polluters form their expectations with respect to regulatory threats based on previous

364 inspections (Shimshack and Ward, 2005, 2008). Previous studies have shown that facilities

365 adopt P2 practices to avoid compliance costs or reduce future inspections (Sam, 2010;

366 Harrington, 2012). An increase in the average number of inspections on sibling facilities

367 owned by the parent firm two years before the current period may lead siblings to adopt

368 more P2 practices one year prior to the current period, which would give our instruments

369 predictive power with respect to cumulative lagged sibling P2 adoption.

370 We believe the exclusion restriction is likely to hold because any direct effect of

371 sibling inspections on own P2 adoption is likely to operate through impacts on own

372 inspections. For example, a facility manager observing an increase in inspections of

373 siblings may adopt additional P2 practices in response, but only because she expects a

374 greater number of inspections on her facility in the near future. Although we cannot directly

375 observe expectations regarding own inspections, the exclusion restriction seems likely to

376 hold once we condition on facility's own lagged environmental inspections as well as all

377 other terms held fixed in equation (3). Additionally, environmental inspection is likely

378 driven by policy and enforcement variation across industries and states, as well as the

379 ability of the community around polluters to apply public pressure (Helland, 1998). These

380 factors driving inspections on siblings in the lagged periods are likely to be exogenous to

381 a facility's own environmental performance in the current period. Nevertheless, we subject

382 our identifying assumptions to robustness checks, as described later in the paper.

383 Finally, since we include own lagged adoption in equation (3) to control for

384 facility's learning from its own experience, we use the second lag of facility's own P2 
385 adoption $\left(T_{i j z d t-2}\right)$ as an instrument to deal with the endogeneity of $\Delta T_{i j z d t-1}$. Following 386 the literature on dynamic panel data models (Anderson and Hsiao, 1981), we assume that

387 sequential exogeneity holds, i.e. that the error term in equation (3) is uncorrelated with past 388 values of own and sibling P2 adoption but may be correlated with their future values 389 (Wooldridge, 2010). If sequential exogeneity holds, the validity of the exclusion restriction 390 is ensured. To summarize, we use 2SLS IV estimation on two endogenous variables

391 (lagged Spillover and Lagged own P2 adoption) with three instrumental variables (second

392 lag of own P2 adoption and second lags of the average number of inspections on siblings

393 by state and EPA). We test orthogonality of the IVs to the error terms and their correlation

394 with the endogenous variables using Hansen's J statistics and rk statistics, respectively

395 (Baum, Shaffer, and Stillman 2005). To assess endogeneity, we compare the spillover

396 effect obtained with and without instrumental variables using a Hausman test.

399 Our data include manufacturing facilities (2-digit SIC codes between 20 and 40) located in 400 the lower 48 U.S. states that belong to a firm with at least two TRI facilities from 1991 to 401 2011. In 1995, 1998, 2000, 2001, and 2011, the EPA changed the TRI chemical

402 requirements and the reporting thresholds to include more reportable chemicals and 403 industry sectors (U.S. EPA, 2017). In this analysis, we focus on 295 chemicals that have 404 been consistently reported to the TRI from 1988 onwards and refer to them as the core 405 chemicals. Both the dependent variable and Sibling P2 Stock are based on the total number 406 of $\mathrm{P} 2$ practices for the 295 core chemicals reported by a facility in a given year. 
To access data on facility and firm characteristics other than P2 adoption and 408 emissions, we use facility-specific data from the National Establishment Time-Series 409 (NETS) database (Walls and Associates, 2011). ${ }^{\text {vi }}$ In order to merge the TRI with the NETS 410 database, we used the facility TRI identifier provided by the NETS, to merge the TRI with

411 the NETS database. The resulting set of facility characteristics includes annual sales (in

412 dollars), number of employees, facility ownership type, facility and headquarters location,

413 SIC codes, and Dun and Bradstreet (D\&B) parent company identification numbers. We

414 identify sibling facilities as those that belong to the same parent company in a given year 415 using parent company information.

416 To obtain data on the inspections and penalties incurred by each facility, we use the

417 facility TRI identifier to merge our data set with the EPA's AIRS Facility Subsystem 418 database (U.S. EPA, 2012). We aggregate the total number of inspections at a facility each

419 year and separate inspections conducted by EPA and local state agencies. We use the 420 county and state location of each facility to merge the dataset on county-level 421 unemployment rate (U.S. BLS, 2011).

422 Appendix Figure 1 shows the percentage of TRI facilities in our sample that 423 reported the adoption of P2 practices at least once. Since the inception of P2 reporting,

424 the rate of adoption increased, then fell over time, following an S-shaped curve.

425 Appendix Figure 2 shows that the average number of new P2 practices adopted each year

426 by TRI facilities declined from 1.5 to 0.25 over the sample period, perhaps because the

427 marginal benefits of additional P2 practices decreased once a facility began to adopt P2

428 practices (Sam, 2010; Harrington 2012, 2013). Additionally, the firm-level Sibling P2

429 Stock increased from 10 to 90 over the sample period as shown in the Appendix Figure 3. 
430 Table 1 provides summary statistics of the explanatory variables, instrumental variables,

431 and dependent variable used in the empirical analysis.

432

\section{[Insert Table 1]}

\section{6. Results}

\section{First stage results}

435 Estimates corresponding to the first-stage estimation of equation (3) are presented in Table

436 2. In columns 1 and 2, we present the coefficients and the standard errors from regressing 437 the first-differenced lagged own adoption $\left(\Delta T_{i j z d t-1}\right)$ on three instrumental variables and 438 other covariates. Columns 3 and 4 report the coefficients and the standard errors from 439 regressing lagged first-differenced sibling P2 stock $\left(\Delta s_{(i) j t-1}\right)$ on the same set of variables.

440 As expected, the number of $\mathrm{P} 2$ practices adopted by a facility two periods prior $\left(T_{i j z d t-2}\right)$

441 is negative and strongly correlated with $\Delta T_{i j z d t-1}$ by construction, since $\Delta T_{i j z d t-1}=$ $442 T_{i j z d t-1}-T_{i j t z d-2}($ column 1, row 1, table 2).

443 Environmental inspections on sibling facilities two periods prior are significantly 444 correlated with the lagged first-differenced stock $\left(\Delta s_{(i) j t-1}\right)$ (column 3, rows 2 and 3), but

445 they do not significantly affect facility's own first-differenced lagged adoption $\left(\Delta T_{i j z d t-1}\right.$,

446 column 1, rows 2 and 3, table 2). As we would expect, the coefficients on each of the two

447 instrumental variables on inspections for $\Delta s_{(i) j t-1}$ are negative, since each instrument is

448 likely to be positively correlated with $s_{(i) j t-2}$, and $\Delta s_{(i) j t-1}=s_{(i) j t-1}-s_{(i) j t-2}$. The

449 Hansen's J statistics for orthogonality of all three instruments is not statistically significant

450 at the $5 \%$ significance level, implying that we cannot reject orthogonality of the

451 instruments. The instruments are strongly correlated with the endogenous variables, 
452 indicated by the statistically significant rk statistics. Note that the rk statistics are valid even

453 with a non-i.i.d. error term (Baum, Shaffer, and Stillman, 2005; Correia, 2017).

454 Additionally, Hausman test on the estimated coefficients on Sibling P2 Stock with and

455 without IV rejects the null hypothesis that the two effects are equal (test statistics $\chi^{2}(1)=$

4566.739 , p-value $=0.001)$, implying that IV is indeed necessary.

\section{[Insert Table 2]}

\section{Main results}

459 Column 1 of Table 3 presents our estimates of equation (3) without the interactions 460 between lagged Sibling P2 Stock and parent firm network characteristics. Columns 2 461 through 4 of Table 3 present the results with the network characteristics and their 462 interactions with lagged Sibling P2 Stock. We estimate one interaction effect in each model 463 because collinearity prevented precise estimation of all effects in a single specification.

464 More specifically, in column (2) we drop our continuous measure of firm size "Number of 465 siblings" and replace it with an indicator for having more than the median number of 466 siblings, an indicator for having more than the $75^{\text {th }}$ percentile quantity of siblings, and 467 interact the two indicators with Sibling P2 Stock. In columns (3) and (4) we proceed in a 468 similar manner for number of states in which the firm operates and percent of siblings in 469 the same industry, respectively.

\section{[Insert Table 3]}

471 As shown in the first row of Table 3, lagged own P2 adoption has a positive and 472 significant effect on own P2 adoption in the current period. The reported coefficient on 473 lagged own $\mathrm{P} 2$ adoptions is properly interpreted as an elasticity because P2 practices are 474 in natural $\log$ form. The results shown in row 1 of Table 3 indicate a $10 \%$ increase in the 
475 adoption of $\mathrm{P} 2$ practices in the previous year causes a $4.9 \%$ increase in the adoption of $\mathrm{P} 2$ 476 practice in the current year, on average.

477 Lagged Sibling P2 Stock also has a positive and significant effect on own P2 478 adoption in the current period (row 2 of Table 3), where a 10\% increase in the total number 479 of $\mathrm{P} 2$ practices adopted by sibling facilities up to the preceding year increases own adoption 480 of P2 practices in the current year by between $0.77 \%$ and $0.90 \%$ on average. To put our 481 results in context, consider that the mean of lagged Sibling P2 Stock is 66 with a standard 482 deviation of 171. Our estimated coefficient indicates that a one standard deviation increase 483 in the lagged Spillover P2 stock above the sample mean will increase a facility's adoption 484 of $\mathrm{P} 2$ practices by $20 \%$ to $23 \%$ in the current period.

485 In comparison to own lagged P2 adoption by a facility itself, the direct effect of 486 intrafirm spillover approximated by the lagged Sibling P2 Stock is much smaller, a result 487 that is consistent with findings in Harrington (2013). But the importance of spillover effects 488 in spurring P2 adoption is understated by only looking at the results in Table 3. As we 489 discussed in the conceptual framework, spillovers are amplified by multiple feedback 490 channels over the long term. Spillovers give rise to a feedback effect wherein P2 adoption 491 by siblings in the previous period increases a facility's own adoption of $\mathrm{P} 2$ practices in the 492 current period, and this facility's own adoption will then create a spillover effect onto 493 adoption by sibling facilities in the next period. We demonstrate the importance of the 494 feedback effect over time using a simulation after presenting the remainder of our 495 econometric results.

497 Heterogeneous spillover effects 
498 In columns 2 through 4 of Table 3, we allow the effect of lagged Sibling P2 Stock to depend

499 on the firm's network characteristics. Since network characteristics may be correlated with

500 unobserved determinants of own P2 adaptions, we do not claim that the interaction terms

501 measure the casual effect on the impact of lagged sibling P2 stock bought about by

502 changing network characteristics. Rather, our interaction terms will accurately describe

503 how the average effect of lagged Sibling P2 Stock varies in our population of interest as a

504 function of observed network characteristics.

505 In column 2 we present results obtained by adding firm size dummies and their 506 interactions with lagged Sibling P2 Stock to the model. Recall that our firm size variables

507 include a dummy equal to one for facilities owned by firms with more than the median 508 number of facilities (i.e. six TRI facilities) and another dummy equal to one for facilities

509 owned by firms with more facilities than the firm at the $75^{\text {th }}$ percentile (i.e. fourteen TRI

510 facilities). The interaction terms are found in the fifth and sixth rows of Table 3 , while the

511 result in the second row can again be interpreted as the average spillover effect.

512 For facilities owned by firms above the median size, the coefficient of -0.063

513 reported in the fifth row indicates that the average response to a $10 \%$ increase in lagged

514 Sibling $P 2$ stock is 0.63 percentage points lower than the average response among facilities

515 owned by firms at or below the median. For facilities owned by firms above the $75^{\text {th }}$

516 percentile in size, both size dummy variables are equal to one. The sum of the interaction

517 term coefficients reported in rows five and six $(-0.063$ and -0.021$)$ is almost equal to the

518 average spillover effect, indicating that the average spillover effect is approximately zero

519 for firms beyond the $75^{\text {th }}$ percentile of size. 
520 Column 3 reports results obtained when allowing the effect of lagged Sibling P2

521 Stock to depend on the parent firm's geographic scope. Once again, we create two dummy

522 variables: a dummy equal to one for facilities owned by firms operating in more than the

523 median number of states (i.e. four states) and another dummy equal to one for firms

524 operating in more states than the firm at the $75^{\text {th }}$ percentile (eight states). As indicated by

525 the results reported in rows five and six of column 3, greater geographic scope is associated

526 with a smaller average spillover effect. For example, the average spillover effect is -0.021

527 lower among firms operating in more than eight states than the average spillover effect

528 among firms operating in four to eight states.

529 Finally, in column 4 we allow the average lagged Sibling P2 Stock to depend on

530 our measure of network homophily, i.e. the share of facilities operating in the same

531 industry. In contrast to our results for heterogeneous spillover effects by size and

532 geographic scope, greater homophily is associated with a larger average response to an

533 increase in sibling P2 adoption. For facilities owned by firms with the greatest degree of

534 homophily, the average spillover effect is nearly twice the size of the average spillover

535 effect for firms below the median level of homophily.

536

$537 \quad$ Simulated long-term effect of intrafirm spillovers

538 To further illustrate the importance of knowledge diffusion within firms over time, we

539 simulate the number of new P2 practices adopted using a hypothetical firm that has six

540 identical TRI facilities with characteristics equal to the sample means evaluated in year

541 1991. In the initial period of 1991, we assume that each facility has already adopted one

542 P2 practice. A single facility, referred to as the "leader" hereafter, adopts an additional P2 
543 practice in 1991, bringing its total P2 practice to two. The increase in P2 practices adopted

544 by the leader will create a spillover effect onto the leader's five sibling firms (the

545 "follower" facilities), increasing their adoption of P2 practices. Increased adoption by the

546 follower facilities generates further spillovers affecting all facilities within the firm. This

547 feedback process continues over the observed time horizon.

548 To illustrate the process described above, we run 1,000 simulations following the

549 method described in Krisinsky and Robb (1986). At the start of each iteration, we

550 randomly draw the parameters of equation (3) from a multivariate normal distribution with

551 means and a parameter covariance matrix taken from our estimation in column 1 of Table

552 3. We then calculate the resulting path for P2 adoptions by the leader and one of its five

553 sibling followers from 1992 through 2011. The point estimate for P2 practices newly

554 adopted in any given year is given by the average of the 1000 simulations. ${ }^{\text {vii }}$ Additionally,

555 we present the simulated sequence of P2 adoption for both the leader and followers

556 assuming the coefficient of lagged Sibling P2 Stock is zero for comparison.

557 Panels (a) and (b) in Figure 1 depict four paths. The horizontal axis denotes year

558 and the vertical axis denotes predicted number of new P2 practices. In panels (a) and (b),

559 the solid line shows the number of new P2 practices adopted when allowing for spillovers,

560 with panel (a) showing the leader firm and panel (b) the follower. The dotted lines in each

561 panel show new P2 practices adopted without allowing for spillovers. As shown by the

562 solid line in panels (a) and (b), the difference in new P2 practices adopted by the leader

563 and follower facilities diminishes over time, as the spillover effect closes the initial gap

564 between the two firm types. Eventually the facilities reach a steady state where both leader

565 and follower adopt 0.4 additional P2 practices each year with spillovers. 
566 The dashed lines in panels (a) and (b) represent the predicted number of new P2

567 practices for the leader and the follower, respectively, in the absence of spillover effects.

568 When not allowing for spillovers, the steady-state number of P2 practices adopted each

569 year falls by $75 \%$ relative to the case with spillovers, from 0.4 to 0.1 . If we calculate the

570 total number of $\mathrm{P} 2$ practices adopted by all facilities over time under the two scenarios, we

571 find that each facility adopts approximately six more P2 practices with intrafirm spillovers

572 than without over the study period.

573 Panels (a) and (b) compare the spillover and no-spillover scenarios while holding

574 network characteristics fixed at their sample averages. In panels (c) - (h), we show

575 additional simulations with different network characteristics. Specifically, these additional

576 simulations are based on the estimates from columns 2, 3, and 4 in Table 3. Panels (c) - (h)

577 illustrate the simulations for the leader and the follower when the respective firm's

578 characteristics fall below the median (dash-dot line), between median and the 3rd quartile

579 (dash line), and above the 3rd quartile (solid line). Comparing the predicted number of new

580 P2 practices at the steady-state level, we can see that the effect of Sibling P2 Stock is twice

581 as large when the firm's size is below the median relative to firms above the median for

582 both the leader and the follower (panels $\mathrm{c}$ and d). We see similar patterns when the number

583 of states in which the firm operates is below the median versus when the firm operates in

584 more than 4 states (panels e and f). When the level of homophily is above the 75 th

585 percentile (i.e. 100\% similarity), the effect of sibling P2 stock is the greatest, and it is

586 smallest when the level of homophily is below the median, for both the leader and the

587 follower (panels g and h). 
590 Robustness checks

591 We present estimates under alternative assumptions in Table 4. First, we estimate our main

592 specification in column 1 without including the lagged dependent variable while treating

593 lagged Sibling P2 Stock exogenous using pooled OLS. The effect of Sibling P2 Stock

594 becomes insignificant. Second, we treat lagged Sibling P2 Stock with instrumental

595 variables while excluding lagged own adoption in column 2. The effect of Sibling P2 Stock

596 is very close to the main results. Third, we estimate the same model with lagged own

597 adoption but treat lagged Sibling P2 Stock as exogenous (column 3). We use the second

598 lag of own adoption as IV for the lagged own adoption, but we find that the effect of lagged

599 Sibling P2 Stock is statistically insignificant (column 3, row 1). The insignificant estimates

600 for lagged Sibling P2 Stock in columns 1 and 3 are expected as discussed earlier that firm-

601 level time-varying shocks may cause negative correlation between the differenced lagged

602 Sibling P2 Stock with the error term in equation (3). In column 4, we create alternative

603 instruments for the lagged Sibling P2 Stock by only using siblings that are located outside

604 of a facility's home state. Own inspections and sibling inspections could both be driven by

605 the same unobserved factors when facilities are geographically proximate, e.g. policy

606 changes at the county level. By only using out-of-state inspections, we remove this threat

607 to instrument validity. We find that the estimates based on our redefined instruments are

608 similar to our main results, though the magnitude of the coefficient falls from 0.077 to

6090.065 (column 3, row 1).

610 Additionally, we include second lags of each facility's own environmental

611 inspections in column 5 (rows 6 and 7). In our econometric models, we assume that twice- 
612 lagged sibling inspections are only correlated with own adoption in the current period 613 through their correlation with sibling adoption, after conditioning on a variety of fixed 614 effects and observables as described above. But the exclusion restriction would be 615 threatened if sibling inspections are correlated with time-varying firm-level compliance 616 efforts (e.g. federal inspectors target the firm as a whole). Endogeneity in this case could 617 arise because sibling inspections would be correlated with own inspections through the 618 firm-wide compliance shock, and own inspections (even if twice lagged) might be 619 correlated with own adoption. We assess this possibility by conditioning on own twice620 lagged inspections. We find that these further lags of facility's own inspections are 621 statistically insignificant.

622 The variable Sibling P2 Stock includes P2 practices adopted by siblings from the 623 beginning period to the preceding year. It is likely that some of the earlier knowledge may 624 have become obsolete, and this cumulative measure should be depreciated over time. We 625 report another set of robustness check in Table 5, in which we modify the variable of 626 Sibling P2 Stock by only accounting for P2 practices adopted by siblings in the previous 627 period. In other words, we check the extreme case of placing zero weight on knowledge 628 accumulated more than one year prior to the current period. We find that the effect of 629 Sibling P2 Stock is still positive and statistically significant but is reduced slightly from $6307.7 \%$ to $6.0 \%$ (with lagged own adoption) and $5.7 \%$ (without lagged own adoption), 631 respectively (row 2). Additional robustness checks are discussed in the Appendix, in which 632 the average effect of Sibling P2 Stock increases from $7.7 \%$ to $11 \%$ and $14 \%$ depending on 633 model specifications. 


\section{7. Conclusion}

635 Previous studies focus on public and regulatory pressures as explanations for heterogeneity

636 in the use of P2 practices by TRI facilities. Our study contributes to the literature by

637 quantifying the extent to which the heterogeneity can be attributed to knowledge spillovers

638 within firm and how intrafirm spillover effects are influenced by a firm's network structure.

639 Using first-differenced instrumental variable estimators, we find a positive and

640 statistically significant intrafirm spillover effect on the number of P2 practices adopted by

641 a TRI facility, in addition to a positive and significant effect from a facility's own lagged

642 P2 adoption. More specifically, we find that a one standard deviation increase in the total

643 number of P2 practices adopted by sibling facilities in the preceding year (i.e., the

644 knowledge stock) increases in the number of P2 practices adopted by a facility in the

645 current year by between $20 \%$ and $23 \%$, on average. Additionally, the spillover effect is

646 stronger for facilities with a high percentage of siblings operating in the same industry. In

647 contrast, the spillover effect diminishes as the number of sibling facilities and the number

648 of states in which firms operate increases.

649 Our results have implications for evaluating the effects of grants or assistance 650 programs to encourage $\mathrm{P} 2$ adoption for reducing toxic waste and greenhouse gas emissions

651 voluntarily in the U.S. First, we find that intrafirm spillovers are significant drivers of P2 652 diffusion within firms. The budget for P2-related programs implemented by the EPA was

653 \$11 million in 2016 and \$13 million in 2017 in addition to P2-related programs initiated

654 by states. To the extent that policies to encourage P2 adoption succeed in increasing the

655 number of adopted P2 practices at targeted facilities, overall policy effects will be under-

656 estimated if spillovers are not considered. The available empirical evidence suggests some 
657 state policies encouraging P2 adoption are indeed effective (O'Rourke and Lee, 2004;

658 Harrington, 2013; Bui and Kapon, 2012), and that the adoption of P2 practices leads to

659 reduced toxic releases by $20-30 \%$ over a five-year time horizon (Harrington, Deltas, and

660 Khanna, 2014). Our results suggest that policies to promote P2 adoption may be more

661 effective than previously believed because of intrafirm spillovers.

662 Second, our empirical results provide support for earlier studies based on surveys

663 and interviews (e.g., Lenox et al., 2000) that suggest intrafirm efforts to disseminate and

664 promote best environmental practices are important drivers for diffusion of best practices.

665 Through simulations, we find that both leader and sibling facilities reach a higher level of

666 P2 adoption thanks to spillovers. It is likely that the observed heterogeneity in both firm-

667 level and facility-level P2 adoption is partly attributable to differing abilities to internalize

668 and diffuse knowledge within firms. Thus, including intrafirm information dissemination

669 mechanisms in the design of P2 assistance program may improve the intensity of P2 670 adoption.

671 Third, we find that the spillover effect within a firm varies by the size and/or com672 plexity of a firm's network. Specifically, the effect of intrafirm spillover is stronger for 673 firms below the median size in our sample and for firms that operate in a single state. To

674 facilitate P2 diffusion, P2 assistance programs should target firms with operations in mul675 tiple jurisdictions and facilitate intrafirm information sharing. This may also apply to 676 other OECD countries that are establishing reporting system following the example of the

677 TRI with the intention to facilitate the exchange of information on best available P2 tech678 niques (OECD, 2018). 
680 of $\mathrm{P} 2$ practices within firms are consistent with studies on knowledge spillovers and

681 knowledge sharing across firms using data on patent citations. Those studies have identi-

682 fied that geographical, technical, and social proximity influence knowledge spillovers and 683 sharing (see review in Jaffe and Rassenfosse, 2017). Similarly, we find that similarity be-

684 tween siblings enhance knowledge spillovers, while larger network and geographical

685 scope impedes knowledge spillovers. Admittedly, our measures of network characteris-

686 tics do not perfectly capture connection diversity, strength, and complexity within firms.

687 Additionally, we do not focus on diffusion of P2 practices among geographic neighbors

688 or within an industry. These limitations can be addressed by future studies.

689

690 References

691 Anderson, T.W., Hsiao, C., 1981. Estimation of dynamic models with error components. 692 Journal of the American statistical Association 76(375), 598-606.

693 Abrahamson, E., Rosenkopf, L., 1997. Social network effects on the extent of innovation 694 diffusion: A computer simulation. Organization Science 8(3), 289-309.

695 Bass, F. M., 1969. A new product growth for model consumer durables. Management Sci$696 \quad$ ence 15 (5): 215-227.

697 Bass, F. M., 2004. Comments on "a new product growth for model consumer durables the 698 Bass Model”. Management Science 50(12):1833-1840.

699 Battisti, G., Stoneman, P., 2003. Inter-and intra-firm effects in the diffusion of new process 700 technology. Research Policy 32(9), 1641-1655.

701 Battisti, G., Stoneman, P., 2005. The intra-firm diffusion of new process technologies. In702 ternational Journal of Industrial Organization 23(1), 1-22. 
703 Baum, C. F., Schaffer, M. E., Stillman, S., 2007. Enhanced routines for instrumental vari704 ables/GMM estimation and testing. Stata Journal 7(4), 465-506.

705 Bellemare, M., Wichman, C., 2018. Elasticities and the Hyperbolic Sine Transformation.

706 Working Paper, Department of Applied Economics, University of Minnesota.

707 Berchicci, L., 2013. Towards an open R\&D system: Internal R\&D investment, external 708 knowledge acquisition and innovative performance. Research Policy 42(1), 117$709 \quad 127$.

710 Besley, T., Case, A., 1993. Modeling technology adoption in developing countries. The 711 American Economic Review 83(2), 396-402.

712 Bhupendra, K.V., Sangle, S., 2015. What drives successful implementation of pollution 713 prevention and cleaner technology strategy? The role of innovative capability. $714 \quad$ Journal of Environmental Management 155, 184-192.

715 Bi, X., Khanna, M., 2012. Reassessment of the impact of the EPA's voluntary 33/50 pro716 gram on toxic releases. Land Economics 88(2), 341-361.

717 Bi, X., Khanna, M., 2017. Inducing pollution prevention adoption: effectiveness of the $71833 / 50$ voluntary environmental program. Journal of Environmental Planning and 719 Management 60 (12), 2234-2254.

720 Brouhle, K., Graham, B., Harrington, D.R., 2013. Innovation under the climate wise pro721 gram. Resource and Energy Economics 35(2), 91-112.

722 Bui, L.T., Kapon, S., 2012. The impact of voluntary programs on polluting behavior: Evi723 dence from pollution prevention programs and toxic releases. Journal of Environ724 mental Economics and Management 64(1), 31-44. 
725 Christmann, P., 2000. Effects of "best practices" of environmental management on cost

726 advantage: The role of complementary assets. Academy of Management Journal

$727 \quad 43(4), 663-680$.

728 Cohen, W., Levinthal, D., 1989. Innovation and learning: the two faces of R\&D. Eco-

729 nomic Journal 99, 569-596.

730 Correia, S., 2017. Linear models with high-dimensional fixed effects: An efficient and

731 feasible estimator. Working Paper. (http://scorreia.com/research/hdfe.pdf).

732 Delmas, M. A., Toffel, M. W., 2004. Stakeholders and environmental management prac-

733 tices: an institutional framework. Business Strategy and the Environment 13, 209-

734222.

735 Delmas, M. A., Toffel, M. W., 2008. Organizational responses to environmental demands:

736 Opening the black box. Strategic Management Journal 29, 1027-1055.

737 Doring, T., Schnellenbach. J., 2006. What do we know about geographical knowledge

738 spillovers and regional growth? A survey of the literature. Regional Studies 403, $739 \quad 375-395$.

740 Doshi, A.R., Dowell, G.W.S., Toffel, M.W., 2013. How firms respond to mandatory infor741 mation disclosure. Strategic Management Journal 34(10), 1209-1231.

742 Downing, P.B., White, L.J., 1986. Innovation in pollution control. Journal of Environmen$743 \quad$ tal Economics and Management 13, 18-29.

744 Earnhart, D., 2004. The effects of community characteristics on polluter compliance levels. $745 \quad$ Land Economics 80(3), 408-432. 
746 Earnhart, D., Leonard, J.M., 2013. Determinants of environmental audit frequency: The role of firm organizational structure. Journal of Environmental Management 128, $497-513$.

749 Earnhart, D., Leonard, J.M., 2016. Environmental audits and signaling: The role of firm 750 organizational structure. Resource and Energy Economics 44, 1-22.

751 Florida, R., Davison, D., 2001. Gaining from green management: Environmental manage752 ment systems inside and outside the factory. California Management Review 43(3), $64-84$.

754 Flight, R., Palmer, R., 2013. Organizational structure and intra-firm innovation diffusion. The Marketing Management Journal 23(2), 35-57.

756 Fuentelsaz, L., Gomez, J., Polo, Y., 2003. Intrafirm diffusion of new technologies: An em757 pirical application. Research Policy 32(4), 533-551.

758 Fung, A., O'Rourke, D., 2000. Reinventing environmental regulation from the grassroots 759 up: Explaining and expanding the success of the Toxics Release Inventory. Environmental Management 25 (2), 115-127.

761 Gray, W.B., Shadbegian, R.J., 2007. The environmental performance of polluting plants: 762 A spatial analysis. Journal of Regional Science 47(1), 63-84.

763 Griliches, Z., 1957. Hybrid Corn: An exploration in the economics of technological 764 change.” Econometrica, 25(4): 501-522.

765 Gruber, K., 2018. Cleaning up pollutants to protect future health. Nature 555, S20-S22, $766 \quad 1-5$.

767 Gupta, A.K., Govindarajan, V., 2000. Knowledge flows within multinational corporations. $768 \quad$ Strategic Management Journal, 21(4), 473-496 
769 Guler, I., Guillén, M.F., Macpherson, J.M., 2002. Global competition, institutions, and the

770 diffusion of organizational practices: The international spread of ISO 9000 quality 771 certificates. Administrative Science Quarterly 47, 207-232

772 Hamilton, J. T., 1995. Pollution as news: media and stock market reactions to the toxics 773 release inventory data. Journal of Environmental Economics and Management 28 $774 \quad$ (1): $98-113$.

775 Harrington, D.R., 2012. Two-stage adoption of different types of pollution prevention 776 (P2) activities. Resource and Energy Economics 34(3), 349-373.

777 Harrington, D.R., 2013. Effectiveness of state pollution prevention programs and poli778 cies. Contemporary Economic Policy 31(2), 255-278.

779 Harrington, D.R., Deltas, G., Khanna, M., 2014. Does pollution prevention reduce toxic $780 \quad$ releases? A dynamic panel data model. Land Economics 90(2), 199-221.

781 Helland, E., 1998. The revealed preferences of state EPAs: Stringency, enforcement and 782 substitution. Journal of Environmental Economics and Management 35, 242-261.

783 Hollenstein, H., Woerter, M., 2008. Inter- and intra-firm diffusion of technology: The ex784 ample of e-commerce: An analysis based on Swiss firm-level data. Research Policy 785 $37(3), 545-564$.

786 Inkpen, A.C., Tsang, E. W. K., 2005. Social capital, networks, and knowledge Transfer. 787 The Academy of Management Revie 30(1), 146-165

788 Jaffe, A. B., De Rassenfosse, G., 2019. Patent citation data in social science research: Over789 view and best practices. In Research Handbook on the Economics of Intellectual $790 \quad$ Property Law. Edward Elgar Publishing. 
791 Jaffe, A.B., Newell, R.G., Stavins, R.N., 2003. Technological change and the environment. 792 Handbook of Environmental Economics 1, 461-516.

793 Jaffe, A.B., Trajtenberg, M., Henderson, R., 1993. Geographic localization of knowledge 794 spillovers as evidenced by patent citations. The Quarterly Journal of Economics $795 \quad 108(3), 577-598$.

796 Karshenas, M., Stoneman, P.L., 1993. Rank, stock, order, and epidemic effects in the dif797 fusion of new process technologies: An empirical model. The RAND Journal of $798 \quad$ Economics 24(4), 503-528.

799 Karshenas, M., Stoneman, P.L., 1995. Technological diffusion. In Stoneman, P. ed., Hand800 book of the Economics of Innovation and Technological Change. Blackwell Pub$801 \quad$ lishing, Oxford, UK, pp. 265-297.

802 Khanna, M., 2001. Non-mandatory approaches to environmental protection. Journal of 803 Economic Surveys, 15(3), 291-324.

804 Khanna, M., Deltas, G., Harrington, D.R., 2009. Adoption of pollution prevention prac805 tices: the role of management systems and regulatory pressures. Environmental 806 and Resource Economics 44(1), 85-106.

807 King, A., Lenox, M.J., 2000. Industry Self-regulation without Sanctions: The Chemical 808 Industry's Responsible Care Program. Academy of Management Journal 43(4), $809 \quad 698-716$.

810 Konar, S., Cohen, M., 1997. Information as regulation: The effect of community right to 811 know laws on toxic emissions. Journal of Environmental Economics and Manage812 ment 32(1), 109-124. 
813 Kremer, M., Miguel, E., 2007. The illusion of sustainability. The Quarterly Journal of $814 \quad$ Economics 122(3), 1007-1065.

815 Krinsky, I., Robb, A. L., 1986. On approximating the statistical properties of elasticities. 816 The Review of Economics and Statistics 715-719.

817 Lenox, M., King, A., 2004. Prospects for developing absorptive capacity through internal 818 information provision. Strategic Management Journal 25(4), 331-345.

819 Lenox, M., King, A., Ehrenfeld, J., 2000. An assessment of design-for-environment prac820 tices in leading U.S. electronics firms. Interfaces 30(3), 83-94.

821 Manski, C.F., 1993. Identification of endogenous social effects: The reflection problem. $822 \quad$ The Review of Economic Studies 60(3), 531-542.

823 Mahajan, V., Muller, E., Bass, F. M., 1995. Diffusion of new products: Empirical general824 izations and managerial uses. Marketing science 14(3_supplement): G79-G88.

825 Maxwell, J, W., Decker, C.S., 2006. Voluntary environmental investment and responsive 826 regulation. Environmental and Resource Economics 33 (4): 425-439.

827 Midgley, D.F., Morrison, P.D., Roberts, J.H., 1992. The effect of network structure in in828 dustrial diffusion processes. Research Policy 21(6), 533-552.

829 Narayanan, S., Nair, H.S., 2013. Estimating causal installed-base effects: A bias-correction $830 \quad$ approach. Journal of Marketing Research 50(1), 70-94.

831 Ochsner, M., Chess, C., 1996. Pollution prevention's promise, limits, and relevance to 832 planners. CPL Bibliography 11(1), 5-16.

833 Oliver, C., 1991. Strategic responses to institutional processes. Academy of Management $834 \quad$ Review 16(1), 145-179. 
835 Organisation for Economic Co-operation and Development (OECD), 2018. Best Availa-

836

837

838

839

840

841

842 Oster, E., Thornton, R., 2012. Determinants of technology adoption: Peer effects in men843

844

845 Ranson, M., Cox, B., Keenan, C., Teitelbaum, D., 2015. The impact of pollution preven846

847

848

849

850 851

852 853

854

855

856

857

ble Techniques for Preventing and Controlling Industrial Pollution, Activity 2:

Approaches to Establishing Best Available Techniques (BAT) Around the World, Environment, Health and Safety. Environment Directorate, OECD.

O’Rouke, D., Lee. E., 2004. Mandatory planning for environmental innovation: Evaluating regulatory mechanisms for toxics use reduction. Journal Environmental Planning and Management 47(2), 181-200.

strual cup take-up. Journal of the European Economic Association 10 (6), 12631293.

tion on toxic environmental releases from US manufacturing facilities. Environmental Science and Technology 49(21), 12951-12957.

Reibstein, R., 2009. Using the tools of pollution prevention to reduce greenhouse gas emissions. Environmental Law Reporter 39, 10851-10861.

Rosenzweig, P.M., Singh, J.V., 1991. Organizational environments and the multinational enterprise. Academy of Management Review 16(2), 340-361.

Sam, A.G., 2010. Impact of government-sponsored pollution prevention practices on environmental compliance and enforcement: evidence from a sample of U.S. manufacturing facilities. Journal of Regulatory Economics 37(3), 266-286.

Seema, A., Cason, T.N., 1999. Do community characteristics influence environmental outcomes? Evidence from the Toxics Release Inventory. Southern Economic Journal 65(4), 691-716. 
858 Sharma, S., Vredenburg, H., 1998. Proactive corporate environmental strategy and the 859 development of competitively valuable organizational capabilities. Strategic Man$860 \quad$ agement Journal 19(8), 729-753.

861 Shimshack, J.P., Ward, M.B., 2005. Regulator reputation, enforcement, and environmen862 tal compliance. Journal of Environmental Economics and Management 50 (3), $863 \quad 519-540$.

864 Shimshack, J.P., Ward, M.B., 2008. Enforcement and over-compliance. Journal of Envi865 ronmental Economics and Management 55(1), 90-105.

866 Singh, J., 2005. Collaborative networks as determinants of knowledge diffusion patterns. 867 Management Science 51(5), 756-770.

868 Snyder, L.D., Miller, H.H., Stavins, R.N., 2003. The effects of environmental regulation 869 on technology diffusion: The case of chlorine manufacturing. American Economic $870 \quad$ Review $93(2), 431-435$.

871 Szulanski, G., 1996. Exploring internal stickiness: Impediments to the transfer of best 872 practice within the firm. Strategic Management Journal 17(S2), 27-43.

873 Tsai, C. M., 2008. Integrating intra-firm and inter-firm knowledge diffusion into the $874 \quad$ knowledge diffusion model. Expert Systems with Applications 34(2): 1423-1433.

875 Tsai, W., 2001. Knowledge transfer in intraorganizational networks: Effects of network 876 position and absorptive capacity on business unit innovation and performance. 877 Academy of Management Journal 44(5), 996-1004.

878 Todo, Y., Matous, P., Inoue, H., 2016. The strength of long ties and the weakness of 879 strong ties: Knowledge diffusion through supply chain networks. Research Pol$880 \quad i c y, 45(9), 1890-1906$. 
881 U.S. BLS, 2011. Labor Force Data by County, 2011 Annual Averages. U.S. BLS, Wash882 ington, DC (http://www.bls.gov/lau/\#tables).

883 U.S. EPA, 2001. An Organizational Guide to Pollution Prevention. EPA/65/R-01/003

884 August 2001. U.S. EPA, Washington, DC.

885 U.S. EPA, 2010. U.S. Environmental Protection Agency 2010-2014 Pollution Prevention

886 (P2) Program Strategic Plan. U.S. EPA, Washington, DC.

887 U.S. EPA, 2012. National Enforcement and Compliance History Online Data Downloads

888 (http://echo.epa.gov/tools/data-downloads).

889 U.S. EPA, 2019. Toxics Release Inventory (TRI) National Analysis. U.S. EPA, Washing-

890 ton, DC. (https://www.epa.gov/trinationalanalysis).

891 Van Everdingen, Y., Wierenga, B., 2002. Intra-firm adoption decisions: Role of inter-firm 892 and intra-firm variables. European Management Journal 20(6), 649-663.

893 Walls and Associates. (2011). National Establishment Time-Series (NETS) Database. Oak894 land, CA: Walls and Associates.

895 Westphal, J. D., Gulati, R., Shortell, S. M., 1997. Customization or conformity? An insti896 tutional and network perspective on the content and consequences of TQM adop897 tion. Administrative Science Quarterly 4 (2), 366-394.

898 Wooldridge, J. M., 2010. Econometric Analysis of Cross Section and Panel Data. Cam899 bridge, MA: MIT Press.

900 Yen, S.T., Jones, A.M., 1997. Household consumption of cheese: an inverse hyperbolic 901 sine double-hurdle model with dependent errors. American Journal of Agricultural 902 Economics 79(1), 246-251.

903 904 Endnotes 
i Facilities report, "if they have 10 or more full-time employees and manufacture, process, or use any of the TRI chemicals in amounts exceeding 25,000 pounds per year or 10,000 pounds per year for otherwise use" (U.S. EPA, 2019).

ii The original model is set up to produce a S-shaped cumulative adoption curve and the parameters of internal and external influences are estimated with a hazard model using observed adoption rate. Modifications have been proposed to the original Bass model. Since our goal is not to estimate the parameters of a Bass model, we choose a simplified version as in Midgley et al. (1992).

iii In the empirical estimation, we opt to use facility's own lagged adoption to represent the first order effect of facility's own cumulative adoption through $\mathrm{t}-1$. This simpler representation allows us to identify the main effect of interests, sibling P2 stock, while still controlling facility's own ability to learn from its most recent experience. As we discuss later, we use twice-lagged inspections on siblings as IVs for sibling's P2 stock, because they are unlikely to be correlated with facility's own P2 adoption in the current period conditional on facility's own lagged inspections. We expect that controlling facility's own lagged adoption is sufficient to identify our main effect of interest, sibling's P2 stock. If inspections on siblings increased two periods ago, a facility manager may have anticipated increased inspections on her own facility one period ago, and responded by increasing P2 adoption one period ago. Thus, to the extent that inspections on siblings have a direct effect on facility's own adoption after conditioning on own lagged inspections, this direct effect is most likely operate solely through an effect on facility's own adoption one period ago.

${ }^{\text {iv }}$ Due to this specific reporting requirement, only new P2 practices are reported in a given year for a particular TRI chemical, and we cannot observe whether any previously adopted pollution prevention practices were discontinued.

${ }^{v} i h s(y)=\log \left(\sqrt{y^{2}+1}+y\right)$. Bellermare and Wichman (2018) show that elasticity estimates after the inverse hyperbolic sine transformation may be substantially different from models estimated using variables in linear form, particularly if the transformed variable is positive but below 10. In the appendix, we examine how our estimates vary by the assumptions used in the transformation.

vi The TRI report data are from a facility-level database, whereas the NETS data are from an establishmentlevel database. These two databases do not match perfectly. We kept only observations that had a unique corresponding facility in each database for a given year. The matching between the TRI and NETS is based on location, name, and 8-digit sic code for a given year (Walls and Associates, 2011).

vii Confidence intervals of the estimates are available upon request. 
Table 1. Summary statistics (1991 to 2011)

Mean SD.

Dependent Variable

Number of P2 practices adopted (log)

$0.317 \quad 0.743$

Explanatory Variables

Sibling P2 stock $(\log )$

$2.701 \quad 2.374$

Percent of sibling in the same industry

$\begin{array}{ll}0.706 & 0.311\end{array}$

Firm operating in multiple states (dummy)

$0.334 \quad 0.471$

Facility's number of employees (log)

$5.550 \quad 1.307$

Facility's toxic releases $(\log )$

$6.890 \quad 4.884$

Facility's inspections by EPA (frequency)

$0.012 \quad 0.118$

Facility's inspections by State (frequency)

$0.317 \quad 0.728$

Number of siblings (log)

$2.467 \quad 1.106$

Share of parent firm's sales in the industry (percent)

$10.39 \quad 15.68$

Number of TRI facilities in a county (log)

$3.047 \quad 1.270$

County's unemployment rate (percent)

$5.910 \quad 2.415$

Instrumental Variables

Avg. number of inspections on siblings by state

$\begin{array}{ll}0.256 & 0.384\end{array}$

Avg. number of inspections on siblings by EPA

$0.001 \quad 0.061$

Note: $\mathrm{N}=128,421$ 
Table 2. First-stage regression results of endogenous variables and instrumental variables

Lagged Own P2 adoption Lagged Sibling's P2 Stock

\begin{tabular}{|c|c|c|c|c|}
\hline Variables & Coefficient & SE & Coefficient & SE \\
\hline Second lagged P2 adoption & $-0.320 * * *$ & $(0.005)$ & $-0.021 * * *$ & $(0.003)$ \\
\hline $\begin{array}{l}\text { Second lagged sibling inspection by } \\
\text { EPA }\end{array}$ & $3 \times 10^{-5}$ & $(0.004)$ & $-0.160 * * *$ & $(0.021)$ \\
\hline $\begin{array}{l}\text { Second lagged Siblings inspection by } \\
\text { state }\end{array}$ & -0.040 & $(0.028)$ & $-0.141 * * *$ & $(0.042)$ \\
\hline Lagged facility toxic releases & $0.018 * * *$ & $(0.001)$ & $0.003 *$ & $(0.001)$ \\
\hline Lagged facility employment & -0.003 & $(0.004)$ & 0.005 & $(0.008)$ \\
\hline Lagged facility inspection by EPA & -0.008 & $(0.011)$ & 0.021 & $(0.014)$ \\
\hline Lagged facility inspection by state & $2 \times 10^{-4}$ & $(0.002)$ & -0.003 & $(0.002)$ \\
\hline No. of siblings & -0.009 & $(0.006)$ & $-0.277 * * *$ & $(0.014)$ \\
\hline Firm operating in multiple states & 0.013 & $(0.009)$ & $-0.132 * *$ & $(0.020)$ \\
\hline Percent of sibling in the same industry & -0.007 & $(0.017)$ & -0.053 & $(0.036)$ \\
\hline Share of firm's sale in an industry & 0.001 & $\left(3 \times 10^{-5}\right)$ & $-2 \times 10^{-4}$ & $\left(6 \times 10^{-6}\right)$ \\
\hline No. of facilities in a county & $-0.020 *$ & $(0.011)$ & 0.003 & $(0.019)$ \\
\hline County's unemployment rate & $-4 \times 10^{-4}$ & $(0.002)$ & 0.002 & $(0.004)$ \\
\hline Shea Partial R-Squared & 0.215 & & 0.141 & \\
\hline $\begin{array}{l}\text { Over identification test statistics } \\
\text { (Hansen's J) }\end{array}$ & \multicolumn{4}{|c|}{$\begin{array}{c}1.0079 \\
p=0.299\end{array}$} \\
\hline $\begin{array}{l}\text { Weak identification test stats (Wald F } \\
\text { stats.) }\end{array}$ & \multicolumn{4}{|c|}{$27.46^{* * *}$} \\
\hline
\end{tabular}

Note: $\mathrm{N}=101,161$. All explanatory variables are first-differenced. ${ }^{* * *} \mathrm{p}<0.01,{ }^{* *} \mathrm{p}<0.05,{ }^{*} \mathrm{p}<0.10$.

Standard errors in parentheses, clustered at facility level. Firm-level fixed effects and their interactions with year trend; state-level, and industry-level fixed effects (2digit SIC) and their interactions with year dummies are included in all models. The first-stage estimates correspond to the main results reported in column 1 in table 3 . 
Table 3. Main and heterogenous effects of sibling P2 stock

\begin{tabular}{|c|c|c|c|c|}
\hline Variables & $\begin{array}{c}(1) \\
\text { Main }\end{array}$ & $\begin{array}{l}(2) \\
\text { Firm } \\
\text { Size }\end{array}$ & $\begin{array}{c}(3) \\
\text { Firm } \\
\text { scope }\end{array}$ & $\begin{array}{c}\text { (4) } \\
\text { Firm industry } \\
\text { concentration }\end{array}$ \\
\hline Lagged own adoption & $\begin{array}{c}0.494 * * * \\
(0.012)\end{array}$ & $\begin{array}{c}0.493 * * * \\
(0.012)\end{array}$ & $\begin{array}{c}0.493 * * * \\
(0.012)\end{array}$ & $\begin{array}{c}0.494 * * * \\
(0.012)\end{array}$ \\
\hline Lagged sibling P2 stock & $\begin{array}{c}0.077 * * \\
(0.032)\end{array}$ & $\begin{array}{c}0.083^{* *} \\
(0.036)\end{array}$ & $\begin{array}{c}0.090^{* *} \\
(0.040)\end{array}$ & $\begin{array}{c}0.082 * * \\
(0.033)\end{array}$ \\
\hline If firm characteristics above median ${ }^{\mathrm{a}}$ & & $\begin{array}{c}-0.036^{* *} \\
(0.016)\end{array}$ & $\begin{array}{c}-0.061 * * * \\
(0.022)\end{array}$ & $\begin{array}{c}0.019 \\
(0.014)\end{array}$ \\
\hline If firm characteristics above $75^{\text {th }}$ percentile ${ }^{\mathrm{b}}$ & & $\begin{array}{l}-0.020 \\
(0.013)\end{array}$ & $\begin{array}{c}-0.035^{* *} \\
(0.016)\end{array}$ & $\begin{array}{c}0.014 \\
(0.016)\end{array}$ \\
\hline Above median $\times$ Lagged sibling P2 stock $^{c}$ & & $\begin{array}{c}-0.063 * * \\
(0.028)\end{array}$ & $\begin{array}{c}-0.064 * * \\
(0.028)\end{array}$ & $\begin{array}{c}0.023 * * \\
(0.010)\end{array}$ \\
\hline Above $75^{\text {th }}$ percentile $\times$ Lagged sibling P2 stock $^{\mathrm{c}}$ & & $\begin{array}{c}-0.021 * * \\
(0.009)\end{array}$ & $\begin{array}{l}-0.011 \\
(0.009)\end{array}$ & $\begin{array}{c}0.034 * * \\
(0.014)\end{array}$ \\
\hline No. of siblings & $\begin{array}{c}0.021 \\
(0.013)\end{array}$ & & $\begin{array}{c}0.038^{* *} \\
(0.019)\end{array}$ & $\begin{array}{l}0.021^{*} \\
(0.012)\end{array}$ \\
\hline Firm operating in multiple state & $\begin{array}{l}-0.023^{*} \\
(0.014)\end{array}$ & $\begin{array}{c}0.002 \\
(0.018)\end{array}$ & & $\begin{array}{l}-0.013 \\
(0.014)\end{array}$ \\
\hline Percent of siblings in the same industry & $\begin{array}{c}0.002 \\
(0.024)\end{array}$ & $\begin{array}{l}-0.033 \\
(0.023)\end{array}$ & $\begin{array}{c}0.015 \\
(0.025)\end{array}$ & \\
\hline Lagged facility's toxic releases & $\begin{array}{c}-0.012 * * * \\
(0.001)\end{array}$ & $\begin{array}{c}-0.012 * * * \\
(0.001)\end{array}$ & $\begin{array}{c}-0.012 * * * \\
(0.001)\end{array}$ & $\begin{array}{c}-0.012 * * * \\
(0.001)\end{array}$ \\
\hline Lagged facility's employment & $\begin{array}{c}0.003 \\
(0.006)\end{array}$ & $\begin{array}{c}0.004 \\
(0.006)\end{array}$ & $\begin{array}{c}0.003 \\
(0.006)\end{array}$ & $\begin{array}{c}0.003 \\
(0.006)\end{array}$ \\
\hline Lagged facility's inspection by EPA & $\begin{array}{c}0.024 \\
(0.018)\end{array}$ & $\begin{array}{c}0.026 \\
(0.018)\end{array}$ & $\begin{array}{c}0.026 \\
(0.018)\end{array}$ & $\begin{array}{c}0.025 \\
(0.018)\end{array}$ \\
\hline Lagged facility's inspection by State & $\begin{array}{c}0.003 \\
(0.004)\end{array}$ & $\begin{array}{c}0.003 \\
(0.004)\end{array}$ & $\begin{array}{c}0.003 \\
(0.004)\end{array}$ & $\begin{array}{c}0.003 \\
(0.004)\end{array}$ \\
\hline Share of firm's sale in industry & $\begin{array}{c}0.000 \\
(0.000)\end{array}$ & $\begin{array}{c}0.000 \\
(0.000)\end{array}$ & $\begin{array}{c}0.000 \\
(0.000)\end{array}$ & $\begin{array}{c}0.000 \\
(0.000)\end{array}$ \\
\hline No of facilities in a county & $\begin{array}{c}0.035^{* *} \\
(0.015)\end{array}$ & $\begin{array}{c}0.036^{* *} \\
(0.015)\end{array}$ & $\begin{array}{c}0.033^{* *} \\
(0.015)\end{array}$ & $\begin{array}{c}0.036^{* *} \\
(0.015)\end{array}$ \\
\hline County unemployment rate & $\begin{array}{l}-0.004 \\
(0.003)\end{array}$ & $\begin{array}{l}-0.033 \\
(0.023)\end{array}$ & $\begin{array}{l}-0.004 \\
(0.003)\end{array}$ & $\begin{array}{l}-0.004 \\
(0.003)\end{array}$ \\
\hline Observations & & 101,161 & 101,161 & 101,161 \\
\hline Over identification test statistics (Hansen's J) & & 1.147 & 1.001 & 1.007 \\
\hline P-value of Hansen's J & & 0.284 & 0.317 & 0.316 \\
\hline Weak identification test statistics (Wald F stats.) & & 10.43 & 9.636 & 11.40 \\
\hline
\end{tabular}

Note: All variables are first-differenced. Robust standard errors in parentheses and are clustered at the facility level. $*_{* *} \mathrm{p}<0.01, * * \mathrm{p}<0.05, * \mathrm{p}<0.10$. Firm-level time trend and industry 2 digit SIC-year and state-year fixed effects are included. Firm size is defined by the number of siblings, firm scope is defined by the number of states the firm operates, and firm industry concentration is defined by the percentage of sibling facilities that belong to the same industry. ${ }^{a}$ Dummy variable that equals to 1 if firm's characteristics of interests is greater than the sample median. ${ }^{\text {b }}$ Dummy variable that equals to 1 if firm's characteristics of interests is greater than the third quartiles. ${ }^{\mathrm{c}}$ Firm characteristics are demeaned in the interaction terms. For all models, the Hansen's J statistics indicate the orthogonality of the instrumental variables cannot be rejected. Wald F statistic based on the Kleibergen-Paap rk statistics in the presence of clustered standard errors (Baum, Shaffer, and Stillman 2007). 
Table 4. Comparison with alternative specifications

\begin{tabular}{|c|c|c|c|c|}
\hline Variables & $\begin{array}{l}(1) \\
\text { IV }\end{array}$ & $\begin{array}{c}(2) \\
\text { IV for } \\
\text { lagged } \\
\text { own } \\
\text { adoption }{ }^{\text {a }}\end{array}$ & $\begin{array}{c}\text { (3) } \\
\text { Alternative } \\
\text { IV }^{\mathrm{b}}\end{array}$ & $\begin{array}{c}\text { (4) } \\
\text { IV w. } \\
\text { additional } \\
\text { inspections }\end{array}$ \\
\hline Lagged own adoption & & $\begin{array}{c}0.499 * * * \\
(0.012)\end{array}$ & $\begin{array}{c}0.495 * * * \\
(0.012)\end{array}$ & $\begin{array}{c}0.503 * * * \\
(0.013)\end{array}$ \\
\hline Lagged sibling P2 stock & $\begin{array}{c}0.073 * * * \\
(0.028)\end{array}$ & $\begin{array}{l}-0.002 \\
(0.003)\end{array}$ & $\begin{array}{c}0.065^{* *} \\
(0.026)\end{array}$ & $\begin{array}{l}0.064^{*} \\
(0.033)\end{array}$ \\
\hline Lagged facility's toxic releases & $\begin{array}{c}0.000 \\
(0.001)\end{array}$ & $\begin{array}{c}-0.012 * * * \\
(0.001)\end{array}$ & $\begin{array}{l}-0.012 * * * \\
(0.001)\end{array}$ & $\begin{array}{c}-0.012 * * * \\
(0.001)\end{array}$ \\
\hline Lagged facility's employment & $\begin{array}{c}0.003 \\
(0.004)\end{array}$ & $\begin{array}{c}0.003 \\
(0.006)\end{array}$ & $\begin{array}{c}0.003 \\
(0.006)\end{array}$ & $\begin{array}{c}0.002 \\
(0.006)\end{array}$ \\
\hline Lagged facility's inspection by EPA & $\begin{array}{c}0.021 \\
(0.014)\end{array}$ & $\begin{array}{c}0.026 \\
(0.018)\end{array}$ & $\begin{array}{c}0.024 \\
(0.018)\end{array}$ & $\begin{array}{c}0.018 \\
(0.019)\end{array}$ \\
\hline Lagged facility's inspection by State & $\begin{array}{c}0.003 \\
(0.003)\end{array}$ & $\begin{array}{c}0.003 \\
(0.004)\end{array}$ & $\begin{array}{c}0.003 \\
(0.004)\end{array}$ & $\begin{array}{c}0.003 \\
(0.003)\end{array}$ \\
\hline Second lagged facility's inspection by EPA & & & & $\begin{array}{l}-0.004 \\
(0.020)\end{array}$ \\
\hline Second lagged facility's inspection by State & & & & $\begin{array}{l}-0.004 \\
(0.004)\end{array}$ \\
\hline Number of siblings (log) & $\begin{array}{c}0.014 \\
(0.011)\end{array}$ & $\begin{array}{l}-0.001 \\
(0.009)\end{array}$ & $\begin{array}{c}0.017 \\
(0.012)\end{array}$ & $\begin{array}{c}0.020 \\
(0.013)\end{array}$ \\
\hline Firm operating in more than one state & $\begin{array}{l}-0.015 \\
(0.011)\end{array}$ & $\begin{array}{c}-0.032 * * \\
(0.013)\end{array}$ & $\begin{array}{c}-0.024 * \\
(0.013)\end{array}$ & $\begin{array}{c}-0.032 * * \\
(0.015)\end{array}$ \\
\hline Percent of siblings in same industry & $\begin{array}{l}-0.002 \\
(0.019)\end{array}$ & $\begin{array}{c}-0.002 \\
(0.024)\end{array}$ & $\begin{array}{c}0.001 \\
(0.024)\end{array}$ & $\begin{array}{c}0.001 \\
(0.026)\end{array}$ \\
\hline Share of firm's sale in the industry & $\begin{array}{c}0.000 \\
(0.000)\end{array}$ & $\begin{array}{c}0.000 \\
(0.000)\end{array}$ & $\begin{array}{c}0.000 \\
(0.000)\end{array}$ & $\begin{array}{c}0.000 \\
(0.000)\end{array}$ \\
\hline Number of TRI facilities in a county & $\begin{array}{c}0.028 * * \\
(0.012)\end{array}$ & $\begin{array}{c}0.036 * * \\
(0.015)\end{array}$ & $\begin{array}{c}0.035 * * \\
(0.015)\end{array}$ & $\begin{array}{c}0.037 * * \\
(0.016)\end{array}$ \\
\hline County unemployment rate & $\begin{array}{c}-0.005 * \\
(0.003)\end{array}$ & $\begin{array}{c}-0.004 \\
(0.003)\end{array}$ & $\begin{array}{c}-0.004 \\
(0.003)\end{array}$ & $\begin{array}{l}-0.002 \\
(0.003)\end{array}$ \\
\hline Firm-level time trend & Yes & Yes & Yes & Yes \\
\hline $\begin{array}{l}\text { Industry 2digit SIC-year } \\
\text { and state-year fixed effects }\end{array}$ & Yes & Yes & Yes & Yes \\
\hline Hansen's over identification test & 0.195 & N/A & 0.29 & 2.44 \\
\hline P-value of the overt identification test & 0.659 & N/A & 0.590 & 0.134 \\
\hline Weak identification test & 41.62 & 289 & 74.32 & 24.93 \\
\hline Observations & 101,161 & 101,161 & 101,161 & 90,080 \\
\hline
\end{tabular}

Note: All variables are first-differenced. Robust standard errors in parentheses and are clustered at the facility level. ${ }^{* * *} \mathrm{p}<0.01,{ }^{* *} \mathrm{p}<0.05,{ }^{*} \mathrm{p}<0.10{ }^{\text {a. }} \mathrm{IV}$ for lagged own adoption is second lagged own adoption. ${ }^{b}$ Alternative IVs are the average number of EPA and state inspections on siblings located in different states two period prior. For models with IVs, the Hansen's J statistics indicate the orthogonality of the instrumental variables cannot be rejected. Wald F statistic based on the Kleibergen-Paap rk statistics in the presence of clustered standard errors (Baum, Shaffer, and Stillman 2007). 
Table 5. Effects of the most recent sibling P2 stock

\begin{tabular}{|c|c|c|}
\hline Variables & $\begin{array}{c}\text { (1) } \\
\text { With lagged own } \\
\text { adoption }\end{array}$ & $\begin{array}{c}(2) \\
\begin{array}{c}\text { Without lagged own } \\
\text { adoption }\end{array}\end{array}$ \\
\hline Lagged own adoptions & $\begin{array}{c}0.496 * * * \\
(0.012)\end{array}$ & \\
\hline Lagged sibling's P2 stock & $\begin{array}{c}0.060 * * \\
(0.025)\end{array}$ & $\begin{array}{c}0.057 * * * \\
(0.022)\end{array}$ \\
\hline Lagged facility's toxic releases & $\begin{array}{c}-0.012 * * * \\
(0.001)\end{array}$ & $\begin{array}{c}0.000 \\
(0.001)\end{array}$ \\
\hline Lagged facility's employment & $\begin{array}{c}0.003 \\
(0.006)\end{array}$ & $\begin{array}{c}0.003 \\
(0.004)\end{array}$ \\
\hline Lagged facility's inspection by EPA & $\begin{array}{c}0.024 \\
(0.018)\end{array}$ & $\begin{array}{c}0.021 \\
(0.014)\end{array}$ \\
\hline Lagged facility's inspection by State & $\begin{array}{c}0.003 \\
(0.004)\end{array}$ & $\begin{array}{c}0.004 \\
(0.003)\end{array}$ \\
\hline Number of siblings & $\begin{array}{c}0.009 \\
(0.010)\end{array}$ & $\begin{array}{c}0.003 \\
(0.008)\end{array}$ \\
\hline Firm operating in more than one state & $\begin{array}{c}-0.028 * * \\
(0.013)\end{array}$ & $\begin{array}{l}-0.020^{*} \\
(0.011)\end{array}$ \\
\hline Percent of siblings in same industry & $\begin{array}{c}0.003 \\
(0.024)\end{array}$ & $\begin{array}{l}-0.001 \\
(0.019)\end{array}$ \\
\hline Share of firm's sale in the industry & $\begin{array}{c}0.000 \\
(0.000)\end{array}$ & $\begin{array}{c}0.000 \\
(0.000)\end{array}$ \\
\hline Number of TRI facilities in a county & $\begin{array}{c}0.034 * * \\
(0.015)\end{array}$ & $\begin{array}{r}0.027 * * \\
(0.012)\end{array}$ \\
\hline County unemployment rate & $\begin{array}{l}-0.004 \\
(0.003)\end{array}$ & $\begin{array}{l}-0.005^{*} \\
(0.003)\end{array}$ \\
\hline Firm-level time trend & Yes & Yes \\
\hline $\begin{array}{l}\text { Industry 2digit SIC-year and state-year fixed } \\
\text { effects }\end{array}$ & Yes & Yes \\
\hline Hansen's over identification test & 1.215 & 0.265 \\
\hline P-value of the overt identification test & 0.270 & 0.606 \\
\hline Weak identification test & 27.34 & 41.16 \\
\hline Observations & 101,161 & 101,161 \\
\hline
\end{tabular}

Note: All variables are first-differenced. Robust standard errors in parentheses and are clustered at the facility level. ${ }^{* * *} \mathrm{p}<0.01,{ }^{* *} \mathrm{p}<0.05, * \mathrm{p}<0.10$. We only aggregate sibling's adoption of $\mathrm{P} 2$ practices in the last period in these estimations, as $89 \%$ of the variation in sibling P2 stock can be explained by its most recent lag. For both models, the Hansen's J statistics indicate the orthogonality of the instrumental variables cannot be rejected. Wald F statistic based on the Kleibergen-Paap rk statistics in the presence of clustered standard errors (Baum, Shaffer, and Stillman 2007). 
(a) Average (Leader)

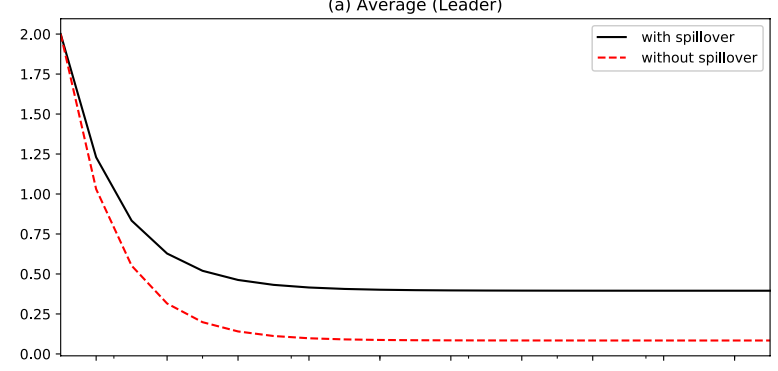

(c) Firm size (Leader)

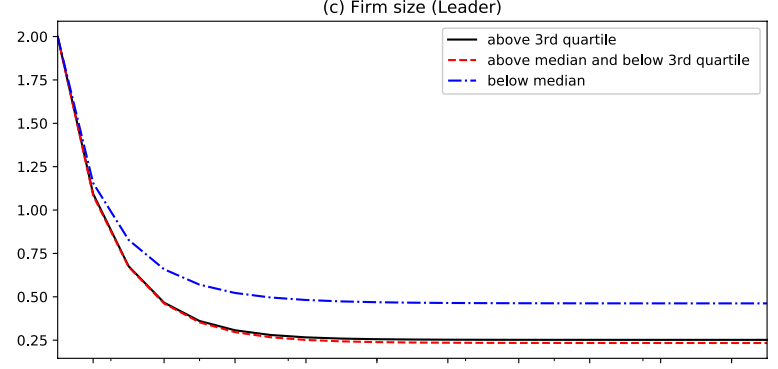

(e) Firm's scope (Leader)

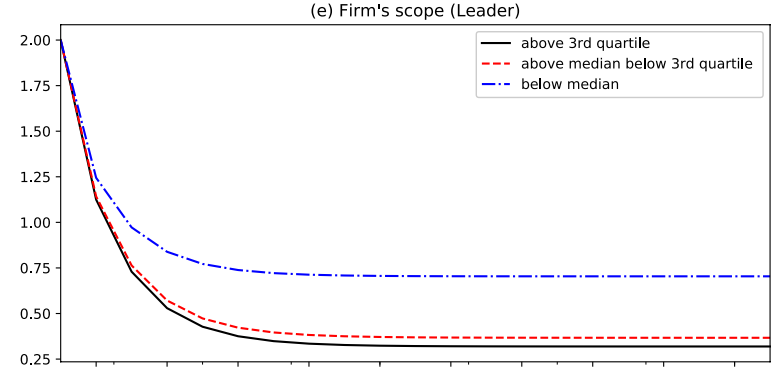

(g) Homophily (Leader)

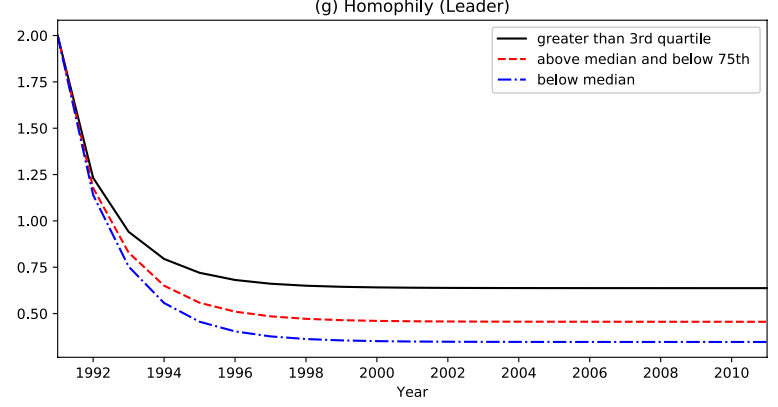

(b) Average (Follower)

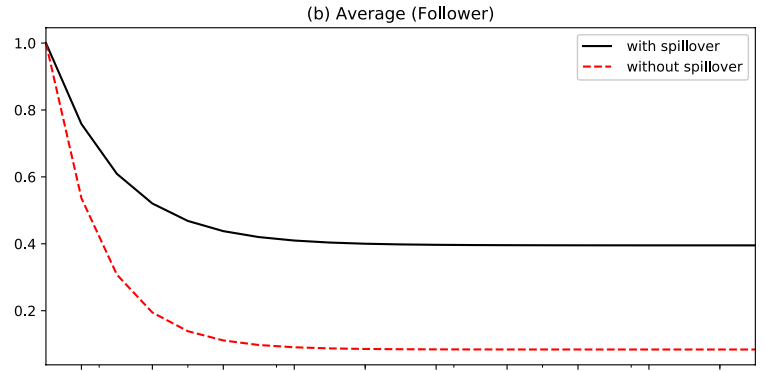

(d) Firm size (Follower)

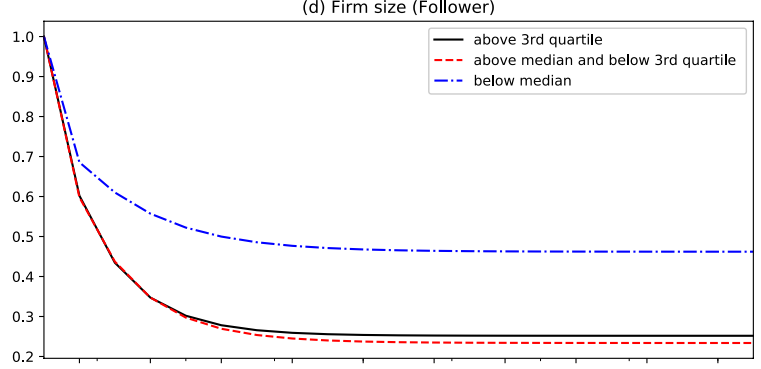

(f) Firm's scope (Follower)

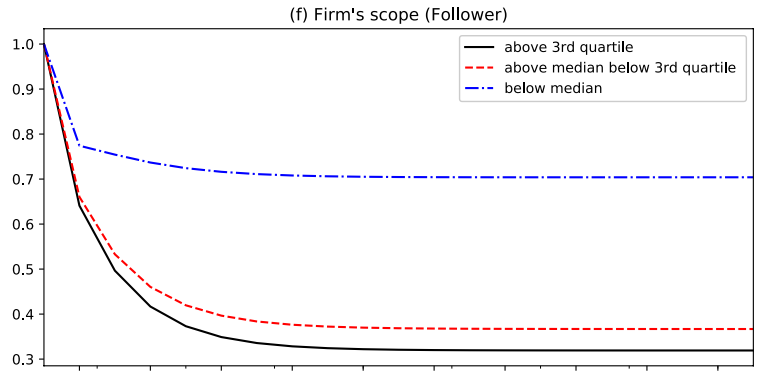

(h) Homophily (Follower)

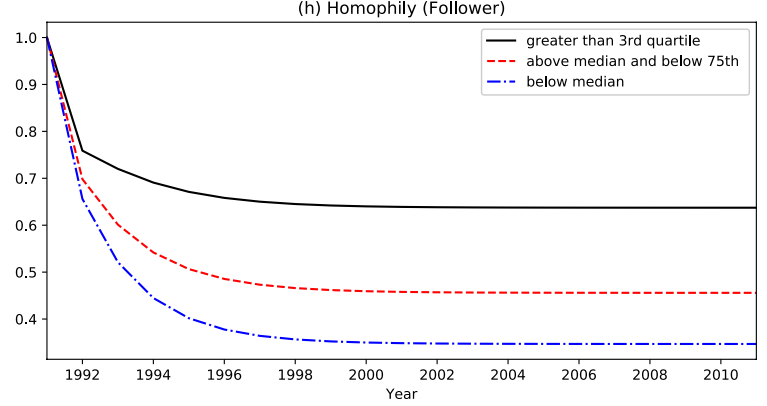

Figure 1. Simulated path of new P2 adoption for leader and follower facility by firm's characteristics 